\title{
The final cut: cell polarity meets cytokinesis at the bud neck in $S$. cerevisiae
}

\author{
Maria Angeles Juanes ${ }^{1,2} \cdot$ Simonetta Piatti $^{1}$
}

Received: 4 February 2016/Revised: 22 March 2016/Accepted: 5 April 2016/Published online: 16 April 2016

(c) The Author(s) 2016. This article is published with open access at Springerlink.com

\begin{abstract}
Cell division is a fundamental but complex process that gives rise to two daughter cells. It includes an ordered set of events, altogether called "the cell cycle", that culminate with cytokinesis, the final stage of mitosis leading to the physical separation of the two daughter cells. Symmetric cell division equally partitions cellular components between the two daughter cells, which are therefore identical to one another and often share the same fate. In many cases, however, cell division is asymmetrical and generates two daughter cells that differ in specific protein inheritance, cell size, or developmental potential. The budding yeast Saccharomyces cerevisiae has proven to be an excellent system to investigate the molecular mechanisms governing asymmetric cell division and cytokinesis. Budding yeast is highly polarized during the cell cycle and divides asymmetrically, producing two cells with distinct sizes and fates. Many components of the machinery establishing cell polarization during budding are relocalized to the division site (i.e., the bud neck) for cytokinesis. In this review we recapitulate how budding yeast cells undergo polarized processes at the bud neck for cell division.
\end{abstract}

Keywords Cytokinesis - Budding yeast - Septins . Actomyosin ring $\cdot$ Mitotic exit network $\cdot$ Formins

Simonetta Piatti

simonetta.piatti@crbm.cnrs.fr

1 Centre de Recherche en Biologie Cellulaire de Montpellier, 1919 Route de Mende, 34293 Montpellier, France

2 Present Address: Brandeis University, 415 South Street, Waltham, MA 02454, USA

\section{Introduction}

Cell division is a fundamental but complex process that gives rise to two daughter cells. It includes an ordered set of events altogether called "the cell cycle" that culminates in cytokinesis, the final stage of mitosis leading to the physical separation of the two daughter cells. Symmetric cell division equally partitions cellular components between the two daughter cells, which are therefore identical to one another and often share the same fate. In many cases, however, cell division is asymmetrical and generates two daughter cells that differ in specific protein inheritance, cell size, or developmental potential [1-3]. An extensively studied example of asymmetric division is that adopted by stem cells, which give rise to one daughter cell that maintains its stemness and self-renewing potential while the other differentiates. The balance between selfrenewal and differentiation is at the basis of tissue homeostasis and, not surprisingly, perturbing this delicate equilibrium can steer hyperproliferation and cancer [4-6].

Asymmetric cell divisions arise from special cellular architectures that make cells polarized, with a basal and apical side or a front and a rear. Cell polarity, however, is an intrinsic property of all types of cells and refers to spatial differences in shape, size and function of the cell. Depending on how the mitotic spindle and the cytokinetic furrow are positioned relative to the polarity axis the ensuing cell division is either symmetric or asymmetric [7] (Fig. 1).

Remarkably, positioning of the cytokinetic furrow is always coupled to spindle positioning (reviewed in [8]). Indeed, in many eukaryotic cells the mitotic spindle provides two non-mutually exclusive furrow-specifying signals $[9,10]$, one that originates from the spindle asters and the other from the central spindle, i.e., the region where 
Fig. 1 Spindle positioning relative to the polarity axis determines the outcome of cell division. The cartoon depicts a polarized cell, where a gradient of polarized factors increases from left to right (gray shadow). Depending on spindle positioning, which dictates the position of the cleavage furrow, cell division will be asymmetric or symmetric

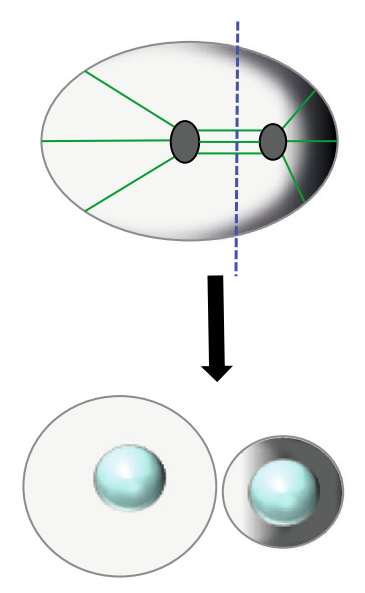

asymmetric

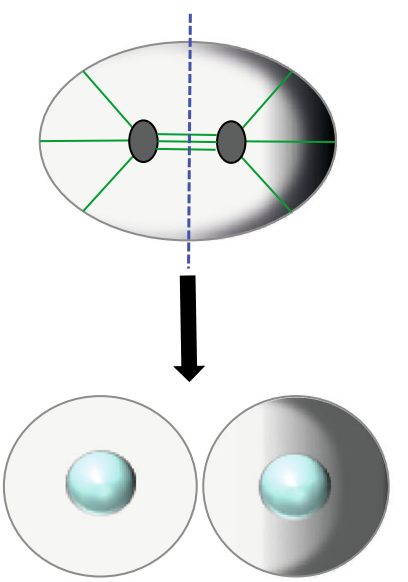

asymmetric
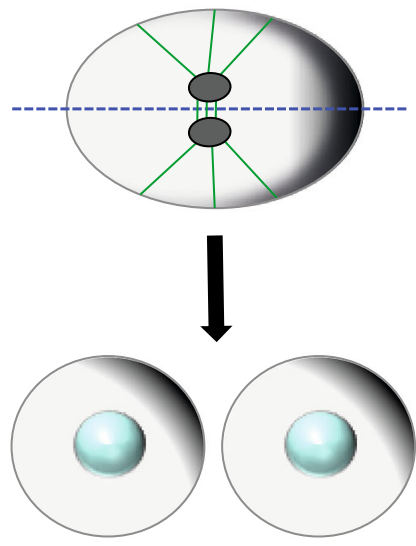

symmetric polar microtubules interdigitate, which dictate positioning of the cleavage plane halfway between the two spindle poles (reviewed in [11]). Nonetheless, in some organisms, such as budding yeasts, where the site of cell division is defined early during the cell cycle and before spindle assembly, specific surveillance mechanisms delay the onset of cytokinesis until the spindle is properly positioned [12, 13]. Thus, cell polarity, spindle positioning and cytokinesis must be carefully orchestrated to ensure the successful physical separation of the two daughter cells, independently of whether cell division is symmetric or asymmetric.

The budding yeast Saccharomyces cerevisiae has proven to be an excellent system to investigate the molecular mechanisms governing cell polarity and cytokinesis. Budding yeast is highly polarized during the cell cycle and divides asymmetrically, producing two cells with distinct sizes and fates. Indeed, a bud emerges from the mother cell at the G1/S transition and keeps growing in size until cytokinesis, when it gives rise to a daughter cell. At this stage the mother cell is normally bigger than its daughter and progressively ages, while its daughter retains full lifespan [14]. Furthermore, mother and daughter cell undergo distinct transcriptional programs that allow, for instance, mating type switching to occur only in the mother cell, while expression of cell wall hydrolytic enzymes is restricted to the daughter cell [15, 16]. Strikingly, many components of the machinery establishing cell polarization during budding are relocalized to the bud neck (the constriction between mother and daughter cell where cytokinesis takes place) later on during the cell cycle for cytokinesis.

Besides these notable features, tractable genetics, powerful biochemistry, proteomics and cell biology approaches make yeast an attractive model for studying the intricate events governing asymmetric cell division, based on the precedent that fundamental principles in the control of cell division were discovered in budding yeast and proved fully applicable to higher eukaryotes.

In this review we recapitulate how budding yeast cells undergo polarized processes at the bud neck for cell division.

\section{Cell polarization}

The ability to polarize is a fundamental property of all types of cells, being crucial for numerous cellular processes such as proliferation, differentiation and development. Simple unicellular eukaryotes, bacteria, cells of multicellular invertebrates or vertebrates are polarized. This results in an extraordinary diversity in the shapes of polarized cells that have been optimized for specialized cell functions, such as the ability to communicate over long distances (neurons), to provide barriers that regulate ion homeostasis between different biological compartments (epithelia), and to unevenly distribute cellular components to daughter cells upon cell division.

At first glance, this diversity of cell shapes and functions suggests that each cell type might have evolved completely different ways to generate cell polarity that distinguishes, for example, budding yeast from a multi-cellular epithelium. Surprisingly, while the final organization of polarized cells is diverse, the basic toolbox of proteins and core mechanisms responsible for polarization are conserved from yeast to humans [17]. Indeed, a common theme in the establishment of a site of polarization is the recruitment of specific lipids and proteins at a given position of the cell surface by membrane traffic along the cytoskeleton. Polarized distribution of macromolecules is achieved by delivery and fusion of vesicles with the plasma membrane (exocytosis), as well as by endocytic internalization and recycling of the molecules that diffuse laterally along the 
membrane. Signaling proteins, such as Rho-like GTPases (e.g. Cdc42 and Rho1) and Rab-like GTPases are then responsible for the reorganization of the cytoskeleton necessary to polarize the cell surface [18].

Defects in cell polarity can lead to cancer formation and metastasis. For instance, the ability of transformed epithelial cells to disseminate to distant organs is linked to a mesenchymal transition where their apico-basal polarity is lost $[19,20]$.

Since much of the cellular machinery that contributes to establishing and maintaining epithelial cell polarity is evolutionary conserved, dissecting polarity establishment in simple models, such as yeasts, has been invaluable to understand the basic principles of this process and its derangement during cancer progression.

\section{Polarized growth in the budding yeast $S$. cerevisiae}

The budding yeast $S$. cerevisiae undergoes highly polarized cell growth throughout its life cycle and follows a stereotypical pattern of growth and division called budding [21, 22] (Fig. 2). Cells first select a site for bud emergence on the basis of cortical landmarks laid in relation to the previous division. Then, an axis of polarity directed toward this site is established by recruitment of signaling molecules. The established site then organizes a cytoskeletal framework targeting secretion for bud emergence. Further cell growth at this stage is mostly restricted to the bud, while the mother cell orchestrates the duplication and segregation of its organelles. Cells then undergo mitosis and cytokinesis, during which polarized secretion is directed to the bud neck to add new membrane and lay down the septum that separates mother and daughter cells.

Most aspects of polarized growth in S. cerevisiae arise from the polarization of the actin cytoskeleton [21-24].
Filamentous actin structures ( $\mathrm{F}$ actin) comprise of (1) actin patches, (2) actin cables and (3) the cytokinetic actin ring.

1. Actin patches are mobile and discrete $F$ actin rich bodies that are nucleated by the Arp $2 / 3$ complex and represent sites of endocytosis. Many endocytic proteins are indeed linked to the Arp2/3 for formation, maturation or scission of the actin patches (reviewed in [25-27]).

2. Actin cables are linear $\mathrm{F}$ actin bundles that act as "tracks" to guide the delivery of secretory vesicles towards the site of growth [28, 29]. They are anchored at discrete regions of the cell cortex (such as the nascent bud site or the bud neck) and radiate through the rest of the cell, underlying the cell cortex [28-30]. Actin cables are nucleated by the conserved diaphanous-related-formins (DRFs, below in detail) Bni1 (Bud-neck involved) and Bnr1 (BNI1-related) [31-33].

3. The cytokinetic F actin ring assembles at the bud neck, contracts and disassembles [34, 35]. This is closely followed by cell wall addition (i.e., septum formation) between the dividing cells. The two formins Bnil and $\mathrm{Bnrl}$ are collectively required for $\mathrm{F}$ actin ring assembly and contraction, with Bnil playing a prominent role $[34,35]$.

As mentioned above, the very first step towards cytokinesis is the selection of an incipient bud site, which is chosen relative to cortical landmarks remaining from the previous cell division [36-38]. Excellent reviews can be found in the literature on this topic [23, 39-41], which therefore will not be treated here. Once the presumptive bud site has been selected in late G1, the actin cytoskeleton becomes highly polarized (Fig. 2). Cortical patches concentrate at the location of the new bud while actin cables emanate from this site. As a bud emerges, cortical patches
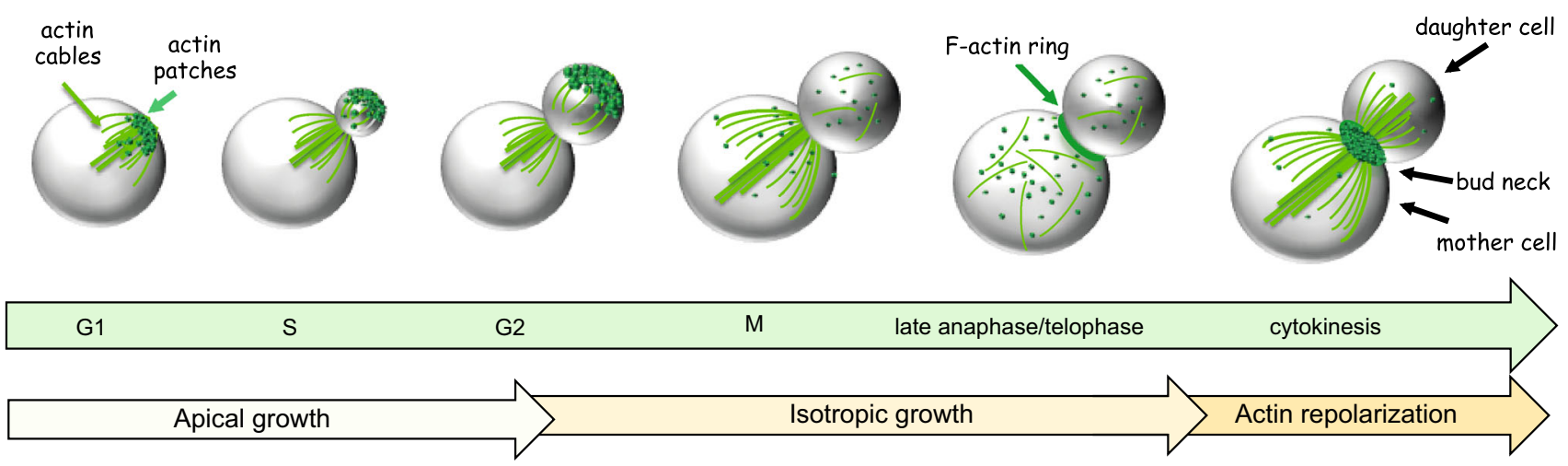

Fig. 2 Organization of the actin cytoskeleton during budding yeast cell cycle. The cartoon illustrates budding yeast cells at different cell cycle stages and the distribution of actin structures (patches, cables and contractile F-ring) therein. Depending on whether actin organization is polarized, cell growth can be apical (directed towards the tip of the bud) or isotropic (with the bud expanding in all directions). After a transient depolarization of actin patches and cables in mitosis, the actin cytoskeleton repolarizes in telophase to bring about cytokinesis. See text for details 
initially cluster at its tip, while cables nucleated at the bud tip extend into the mother cell. This configuration supports trafficking required for bud growth from the tip (apical growth). Later on, patches and cables redistribute randomly within the bud, while cables in the mother cell still extend from the bud neck. During this phase, bud growth continues by expansion in all directions (isotropic growth). Finally, when cells exit mitosis actin repolarization occurs at the bud neck to support cytokinesis; the contractile F actin ring assembles and actin cables direct secretion towards the division site for septum formation (Fig. 2). Actin patches also concentrate at the mother and daughter side of the bud neck [28, 42], presumably for endocytic internalization and/or recycling of cytokinetic factors.

\section{Rho GTPases in the establishment of cell polarity}

Rho GTPases are conserved proteins belonging to the Ras superfamily of small $G$ proteins that are regarded as molecular switches, as they can oscillate between an inactive GDP-bound state and an active GTP-bound state [43, 44]. Like all G proteins, Rho GTPases are endowed with intrinsic GTPase activity. The rate-limiting step in GTPase activation is the release of GDP aided by guanine nucleotide exchange factors (GEFs), which allow GTPasebinding to GTP that in turn is present in the cells at higher concentrations than GDP. Conversely, GTP hydrolysis can be stimulated by GTPase-activating proteins GAPs) that shift the balance to the inactive state of the GTPase [45, 46]. Other regulators of Rho GTPases include the guanine nucleotide dissociation inhibitors (GDIs) that can lock the GTPase in the GDP- or GTP-bound form, as well as extract it from the membrane, thereby preventing its GEF-mediated activation [47].

Establishment of cell polarity in budding yeast requires the Rho GTPase Cdc42, which accumulates at the presumptive bud site through a process involving its GEF $\mathrm{Cdc} 24$ and the scaffold protein Bem1 that bridges Cdc24 to the $\mathrm{Cdc} 42$ effector Cla4, thereby generating a positive feedback loop that clusters $\mathrm{Cdc} 42$ to a single cortical site [48-50]. Cdc42 is further concentrated to a focused vertex by recycling mechanisms that include the GDI Rdil as well as the opposing activities of exo- and endocytosis [51, 52]. Once concentrated at a single focus, active Cdc42 organizes the actin cytoskeleton and septins to promote polarized secretion and cell growth (see below). Known Cdc42 effectors include the partially redundant PAK (p21activated kinases) Cla4 and Ste20, which play major redundant roles in actin and septin organization [53-58], the formin Bni1 ([59], see below), the proteins Gic1 and Gic2, which promote septin recruitment and formin activity ([60-63], see below) and the Sec3 component of the exocyst complex, which plays essential role in exocytosis through vesicle targeting and docking to the plasma membrane [64, 65].

Besides Cdc42, budding yeast has five additional Rho GTPases that are named Rho1-5. Like Cdc42, Rho1 is essential for cell viability and plays a major role in cytokinesis through assembly of the cytokinetic contractile ring and the division septum (see below). Its effectors include formins [66, 67], the glucan synthase Fks1 [68], protein kinase $\mathrm{C}(\mathrm{Pkc1},[69,70])$ and the exocyst subunit Sec3 [71]. In contrast, Rho2-5 are dispensable for survival of yeast cells and their respective roles are ill-defined, although Rho3 and Rho4 share an essential role in the establishment of cell polarity and have been collectively implicated in formin activation $[59,66]$.

\section{Formins as key regulators of cell polarity and cytokinesis}

Formins are large multi-domain proteins found in plants, fungi and mammals. Although their number is highly variable in different organisms, formin structure and function are highly conserved $[72,73]$.

In budding yeast there are two arrays of actin cables, one polarized toward the bud cortex and the other toward the mother-bud neck, that are nucleated by the two formins, Bnil and Bnr1 [31, 32, 67, 74-76]. In budding yeast, neither one of the two formins is essential, but cell viability requires at least one of them [66], suggesting that they share at least one essential function. However, Bnil and Bnr1 clearly also play distinct cellular roles, which is highlighted by their different patterns of cellular localization and respective mutant phenotypes [77-80]. From bud emergence to mitotic exit Bnrl resides at the bud neck, where it is relatively static and nucleates actin cables extending into the mother cell [76, 77, 81]. In contrast, Bni1 localizes throughout most of the cell cycle to the bud tip, where it nucleates actin cables, and to the bud neck immediately before cytokinesis, when it replaces Bnr1, helping to form the contractile actomyosin ring (CAR) [77, 82]. At the bud tip, Bnil binds to several components of the polarisome (i.e., Spa2, Pea2 and Bud6, [31, 83]), a protein complex involved in cell polarity that localizes at sites of polarized growth [84]. Two motifs named SBD (Spa2binding domain) and BBD (Bud6-binding domain) (Fig. 3) have been mapped in the middle and $\mathrm{C}$ terminal region of Bni1, respectively, linking Bni1 to the polarisome [78, 79, 83]. The Spa2-Bnil binding is required for Bnil localization at the bud tip and for proper regulation of actin architecture. Indeed, in the absence of Spa2, Bni1 gets redistributed to the cytosol instead of localizing at bud cortical sites [83]. In contrast, loss of Bud6 has a minor impact on Bni1 localization [31]. However, a $\mathrm{C}$ terminal fragment of Bud6 can stimulate the actin-polymerizing 


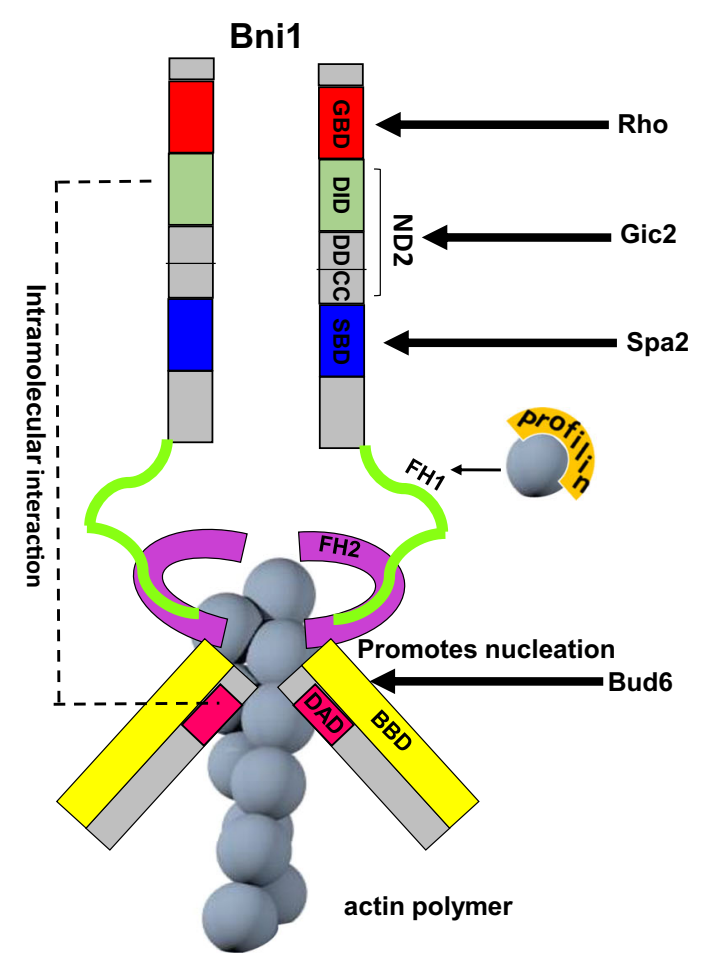

Fig. 3 Structural organization of the yeast formins Bni1 and Bnr1. Formins form a doughnut-shaped dimer that encircles the nascent actin filament during its elongation. The main interactors and regulators of each formin are depicted. See text for details. $G B D$

activity of Bni1, as supported by in vitro experiments that led to the proposal that Bud6 acts as a nucleation-promoting factor [79, 85]. Interestingly, Bud6 can also enhance in vitro actin nucleation by the other formin Bnr1 when assisted by the Bil1 protein (Bud6-interacting ligand) [86], in agreement with previous data showing that the $\mathrm{C}$ terminal part of Bud6 participates in formin-dependent actin cable organization in vivo [78].

Formin recruitment to and release from membranes, as well as its actin-nucleating activity, involve additional formin modifications and/or binding partners that tune their function. The formin homology domain 1 (FH1, Fig. 3) is a proline-rich motif that binds profilin, among other proteins. Profilin is an actin-binding protein that recruits actin monomers to the active region of formin when bound to FH1 [66, 74], thereby stimulating formin-induced actin polymerization [32, 87]. The second formin homology domain (FH2, Fig. 3) lies next to FH1 and is required to form a doughnut-shaped formin dimer that encircles the nascent actin filament during its elongation [88]. Consistently, the dimeric architecture of formin is relevant for its actin nucleation activity [87, 89].

Formins have two additional important regulatory motifs, the DID (Diaphanous Inhibitory Domain) and the DAD (Diaphanous Auto-regulatory Domain) (Fig. 3) that

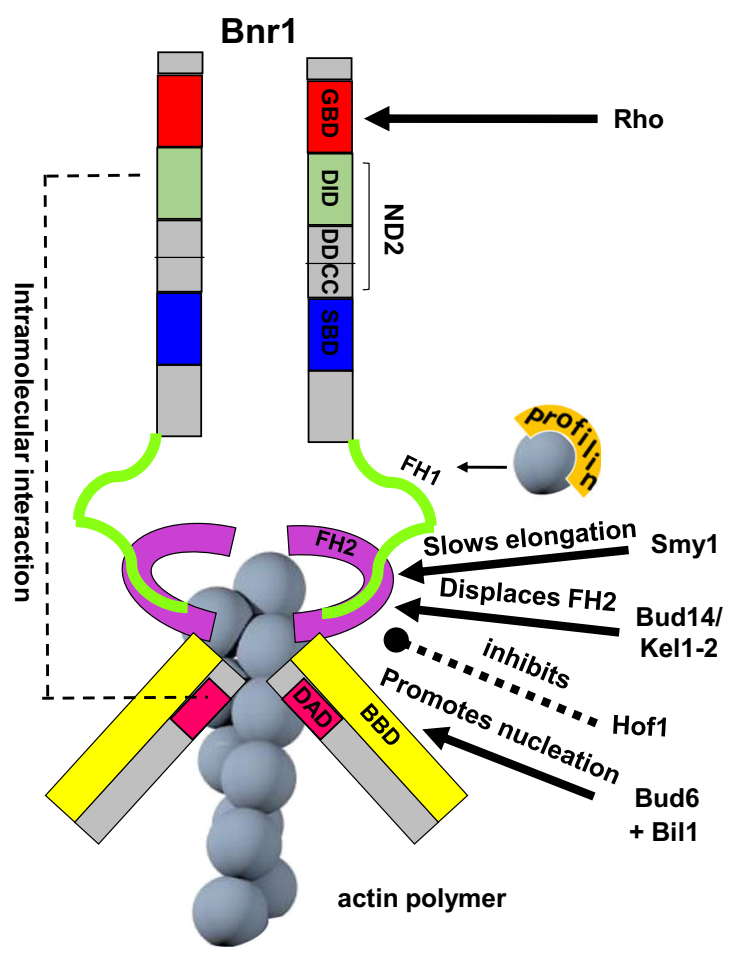

GTPase-binding domain, $D I D$ diaphanous inhibitory domain, $D D$ dimerization domain, $C C$ coiled coil, $S B D$ Spa2-binding domain, $F H 1 / 2$ formin homology domain, $D A D$ diaphanous auto-regulatory domain, $B B D$ Bud6-binding domain

were originally identified in the Drosophila formin Diaphanous [90]. DID and DAD can interact with one another within the same formin molecule, thereby locking formin in a close inhibited state [91, 92]. Other formin domains can relieve this autoinhibition to promote an open and active state. Among them, the GBD (GTPase binding) and the ND2 (N-terminal) domains (Fig. 3) bind to Rho GTPases and the Gic2 protein, respectively, and also control Bni1 localization at the bud tip [62, 93-95]. The GBD is located next to the DID domain, and its binding to Rho relieves formin autoinhibition by hindering DID interaction with DAD [94, 96-100]. Whether formin binding to a Rho GTPase is always necessary for its activation is unclear, especially since other domains can also relieve autoinhibition.

To add additional layers of complexity to formin regulation, other cofactors modulate the biological function of formins. Tropomyosins, which are master regulators of muscle cells contraction, also play key roles in non-muscle cells by controlling actin dynamics and cell migration [101, 102]. In budding yeast, they control assembly and stability of actin cables [103]. Additionally, tropomyosins promote formin-mediated formation of contractile ring assembly in fission yeast [104], raising the possibility that they might play a similar function also in budding yeast. 
Yet another formin regulator is the kinesin-like myosinpassenger protein Smy1, which acts as a Bnr1 damper in vitro and in vivo without affecting Bnil [105, 106]. Smy1 slows down the elongation rate of Bnr1-mediated actin polymerization by direct binding to Bnr1. Accordingly, cells lacking Smy1 show extremely long actin cables with prominent defects in their architecture [105]. Recently, Smy1, Bnr1 and the myosin V motor protein Myo2 that delivers Smy1 to formin have been involved in an "antenna mechanism" that senses and controls the length of actin cables [107].

Another set of formin tuners act in parallel with the ones listed above to ensure proper actin cable architecture. A complex formed by Bud14 and the Kelch-domain proteins Kel1 and Kel2, which are involved in cell polarity and morphogenesis, senses the length of actin cables and eventually displaces Bnr1 from actin filaments [108-110]. Bud14 does not suppress Bnr1 actin-polymerizing activity but rather the permanence of formin on actin, thereby attenuating the elongation rate of actin filaments.

The F-BAR protein Hof1, which controls septin organization and septum deposition ([81, 111, 112], see below), inhibits the actin-nucleating activity of Bnr1 both in vitro and in vivo [113], thereby tuning the architecture of the actin cable network. Conversely, Bnr1 is somehow activated in vivo by septins (see below) and the septinassociated kinase Gin4 [114].

Finally, formin activity is likely controlled by posttranslational modifications. For instance, phosphorylation of Bnil by the Prk1 kinase unleashes its autoinhibition [115]. In mating cells, Bni1 phosphorylation by the Fus3 MAP kinase is important for its localization to and assembly of actin cables [116], while dephosphorylation of both Bni1 and Bnr1 by Cdc14, as well as Bnr1 dephosphorylation by protein phosphatase 1 (the PP1 Glc7), seems to trigger the replacement of Bnr1 with Bni1 during mitotic exit $[117,118]$. Finally, a truncated variant of Bni1 was recently shown to be ubiquitylated in vivo by the Rsp5 E3-ubiquitin ligase and subsequently degraded to reorganize the actin cytoskeleton under stress conditions and wound healing [119].

\section{Actin polarization at the bud neck for cytokinesis}

Just before cell division, the actin cytoskeleton repolarizes to the bud neck (Fig. 2). Thus, actin structures (actin cables, actin patches and the $\mathrm{F}$ actin ring) converge at the cell division site. In particular, actin cables rearrange to be polarized towards the bud neck and ensure that membrane trafficking will bring secretory vesicles and proteins to the cytokinesis site to bring about membrane closure. This remarkable reorganization of the actin cytoskeleton is driven by inactivation of mitotic cyclin B-CDK complexes at mitotic exit $[42,120]$ (see "The mitotic exit network"). Approximately at the same time, many polarity factors, such as the Cdc42 and Rhol GTPases, polarisome components (e.g. Bni1, Spa2 and Bud6) and the exocyst complex, translocate from the bud tip to the bud neck, thus contributing to the actin rearrangements accompanying this transition [76, 81, 82, 84, 121-123]. Most likely, the relocalization of some of these proteins occurs to reinforce Bni1-dependent polymerization of actin cables and ring at the bud neck. While Rho1 presumably directly promotes local Bni1 activation for $\mathrm{F}$ actin ring assembly (see below, [124]), it has not been established if Cdc42 directly activates Bnil for actin polymerization prior to cytokinesis. However, inactivation of the redundant PAK kinases Ste20 and $\mathrm{Cla} 4$, which are known Cdc42 effectors, during mitosis abolishes actin repolarization at the bud neck [55], suggesting that $\mathrm{Cdc} 42$ might have an indirect role in formin activation at cytokinesis. In turn, Ste20, and perhaps Cla4, might regulate Bni1 activity through direct phosphorylation [54, 125]. Interestingly, although Cdc42 persists at the bud neck until cytokinesis has been accomplished, the levels of active GTP-bound Cdc42 decrease at cytokinesis [123, 126, 127]. Inhibition of Cdc42, and Ste20 downstream to $\mathrm{Cdc42}$, is in turn important for efficient recruitment of cytokinesis factors to the bud neck and proper cell division [128]. Consistent with the antagonism between $\mathrm{Cdc} 42$ and Rho1/RhoA that has been shown in many eukaryotic systems, the polo kinase $\mathrm{Cdc5}$ is required for $\mathrm{Cdc} 42$ inhibition while promoting the recruitment of Rho1 to the neck through phosphorylation of one of its guanine nucleotide exchange factors (GEFs) [129, 130].

While Spa2 mediates localization of the formin Bni1 at the bud tip [83], it is dispensable for its redistribution to the bud neck at cytokinesis [82]. However, Spa2 and Bud6 might contribute to formin-dependent actin polymerization. Although the precise mechanism by which Bnil relocates from the bud tip to the neck is still elusive, the Cdc14 phosphatase and Bnil phosphorylation were shown to be involved in this process [117]. A good candidate for promoting Bnil recruitment to the bud neck is the exocyst complex. The exocyst is a conserved protein complex made by eight subunits (Sec3, Sec5, Sec6, Sec8, Sec10, Sec15, Exo70 and Exo84) that tethers exocytic vesicles to the plasma membrane during secretion [131-133]. Inactivation of the exocyst complex through temperature-sensitive mutations leads to disappearance of actin cables and a general depolarization of actin, which suggests that the exocyst regulates actin dynamics [134, 135]. Strikingly, in fission yeast Sec3 is essential for the localization of the formin For3 (the fission yeast counterpart of Bni1) at the plasma membrane where the two proteins interact [136]. Importantly, the distribution and/or activity of the exocyst complex is controlled by both $\mathrm{Cdc} 42$ [64, 137, 138] and 
Rho1 [71], presumably in a reciprocal manner depending on the cell cycle stage, suggesting yet another possible route through which Rho-like GTPases might control formin activity.

\section{The septin ring}

\section{The septin ring and cytokinesis}

Studies in budding yeast and mammalian cells indicate that septins act as scaffold to recruit cytokinetic factors to the site of cell division (reviewed in $[139,140]$ ). Septins were first discovered in budding yeast through a genetic screen for mutants defective in cell division [141] and are cytoskeletal GTP-binding proteins that form oligomeric complexes that can in turn self-organize in higher-order structures, such as filaments and rings. Although septins have been found at the division site in most cell types examined so far, the extent to which they contribute to cytokinesis varies from one organism to another. For example, in the fission yeast $S$. pombe septins appear at the division plane only after the cytokinetic ring has fully assembled [142, 143] and their deletion causes only a mild cell separation defect $[144,145]$. In stark contrast, several of $S$. cerevisiae septins are essential for viability and cytokinesis.

The five septins expressed in vegetative budding yeast cells (Cdc3, Cdc10, Cdc11, Cdc12 and Shs1) form heterooctamers composed by two copies of the core $\mathrm{Cdc} 10, \mathrm{Cdc} 3$ and $\mathrm{Cdc} 12$ subunits and two copies of the alternative septins Cdc11 and Shs1 arranged in palindromic linear rods $[57,146,147]$. The rods collide on the plasma membrane to join end-to-end in non-polar filaments [148] that in turn organize in a ring. Recent data showed that the nonessential yeast septin, Shs1, curves septin filament bundles into rings in vitro and promotes proper septin organization at the bud neck in vivo [147].

The bud neck protein Bni5 had been identified as multicopy suppressor of septin mutants [149] and has been recently shown to crosslink septin filaments in vitro [150], likely providing structural stability to the septin ring in vivo. Bni5 directly interacts with the septins Cdc11 and Shs1, as well as with Myo1, mediating its recruitment to the division site throughout most of the cell cycle until cytokinesis [151-153].

Septins associate with membranes, and in particular with positively charged phosphoinositides, such as phosphatidylinositol-4,5-diphosphate (PIP2) [154], through a highly conserved polybasic region at the $\mathrm{N}$ terminus $[155$, 156]. In budding yeast $\mathrm{PIP}_{2}$ is enriched in membrane areas of polarized growth and the bud neck [157] and it stimulates formation and organization of septin filaments that are in turn essential for cell viability $[154,158]$.

Septins are first recruited to the presumptive bud site as unorganized septin clouds or patches, which are then rapidly transformed into a cortical septin ring in late G1. Fluorescence Recovery After Photobleaching (FRAP) experiments indicate that septin structures prior to bud emergence are highly dynamic. At the time of bud emergence the septin ring expands into a rigid hourglass-like structure referred to as septin collar, which spans the whole bud neck and scaffolds many cytokinetic factors [159, 160]. Immediately prior to cytokinesis the collar splits into two distinct rings that sandwich the contractile actomyosin ring (CAR, see below) and are highly dynamic (reviewed in $[139,140]$ ) (Fig. 4). The physiological relevance of ring splitting for cytokinesis has yet to be elucidated. However, coincident with or immediately after septin-ring splitting the CAR constricts in between the split septin rings and the cleavage furrow ingress, bringing about deposition of the primary septum $[161,162]$. Remarkably, septin ring splitting is accompanied by a striking change in septin arrangement that was revealed by polarized fluorescence microscopy. Indeed, while septin filaments inside the collar are arranged in parallel arrays aligned along the motherbud axis, they are found rotated by $90^{\circ}$ in split septin rings $[163,164]$. How these observations can be reconciled with earlier electron microscopy (EM) studies showing that septin rings are made by circumferential septin filaments encircling the bud neck [165] has been subjected to extensive debate. Recent data obtained by platinum-replica EM and correlative light/EM suggest that the early septin collar is made by double septin filaments oriented along the mother-bud axis, while later on during mitosis it acquires orthogonally oriented circumferential septin filaments that confer a gauze-like appearance to the structure [166]. During septin ring splitting the septin double filaments are somehow depolymerized, leaving two parallel rings of filaments around the bud neck. Interestingly, although the myosin II Myo1 and the non-essential septin Shs1 are not strictly required for septin collar formation, they seem to affect the overall organization of the mature septin collar [166].

The Cdc42 GTPase is essential for septin recruitment to the presumptive bud site $[63,167]$ and cycles of Cdc42 GTP-binding and hydrolysis are required for septin collar formation [159, 168]. Among the known Cdc42 effectors, the paralogous membrane proteins Gic1 and Gic2 seem to play a crucial role in septin recruitment. Accordingly, septin deposition and budding mostly fail in gicl gic2 double mutants at high temperatures [63]. Gic1 localizes at the presumptive bud site and bud tip at early stages of the cell cycle and at the bud neck later on [63], and it has been 
Fig. 4 Main steps in budding yeast cytokinesis. See text for details

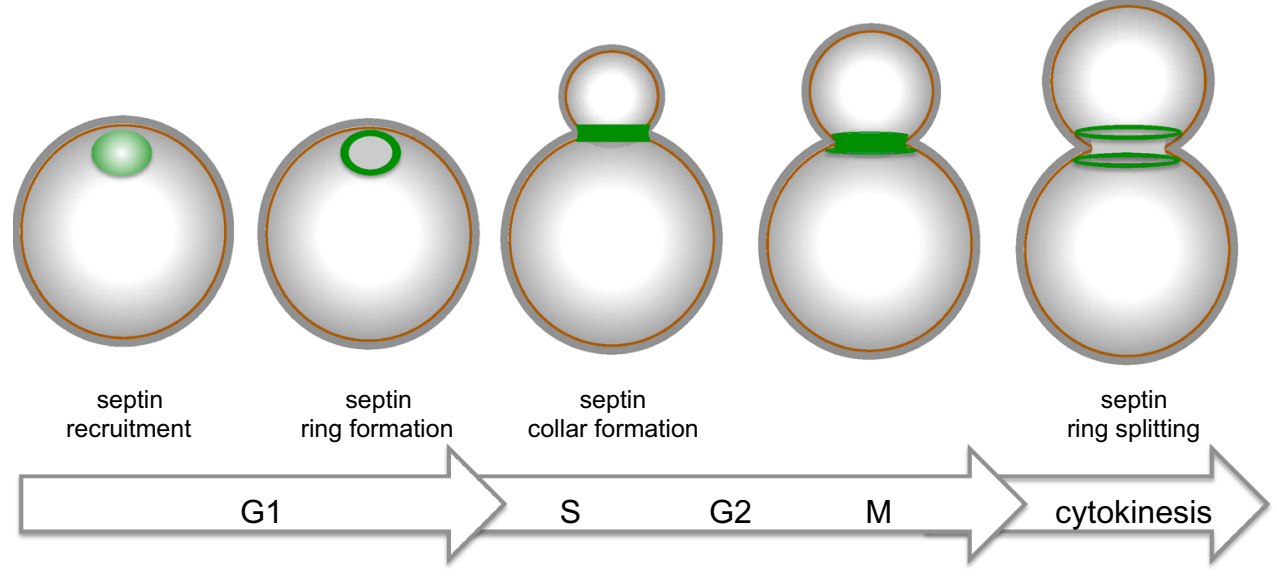

recently shown to bundle and crosslink septin filaments in vitro, thereby stabilizing them [169]. Surprisingly, the inactive GDP-bound form of $\mathrm{Cdc} 42$ was found to bind directly septin filaments and to depolymerize them when present at high concentrations, while creating lateral crosslinks between septin filaments at low concentrations. On the basis of these and other observations it has been proposed that the initial recruitment of septin octamers to the future bud site is promoted by Cdc42-GDP itself; afterwards, septin filaments get bundled and stabilized by Gic1, presumably bound to Cdc42-GTP [169]. Once a polarized cap of septin filaments has been formed at the presumptive bud site, the septin ring is sculpted by polarized exocytosis that creates a hole in the middle of the cap [170]. At cytokinesis, Cdc42 accumulates at the bud neck where it might induce septin depolymerisation [169], to favor recycling of septin octamers for the following cell cycle [171]. Intriguingly, septins inhibit Cdc42 activity at the bud neck in a negative feedback loop through GTPaseactivating proteins, which promote the Cdc42 GDP-bound inactive state [170]. Of note, according to the model proposed by Sadian et al. [169] this event could stimulate, at the same time, further recruitment of septin octamers.

Direct binding to septin filaments and activation of Gic1 and Gic2 are not the only function of Cdc42 in septin regulation. Another Cdc42 effector, the PAK kinase Cla4, directly phosphorylates the septin $\mathrm{Cdc10}$ in vitro and in vivo, thereby preserving the integrity of septin architecture [57]. Furthermore, the formin Bnil, which is another effector of Cdc42 (see above), contributes to septin ring formation along with Cla4 [56].

Anillin is a multi-domain cytokinesis protein that in metazoans interacts with a plethora of partners, including actin, myosin, septins and formins, among many others (reviewed in [172]). In budding yeast, the anillinlike protein Bud4 associates with septins in mitosis and colocalizes with the septin ring until after the next G1 phase, to then disappear at the onset of budding [173, 174]. Bud4 is required to stabilize the septin ring during splitting [162, 175], similar to the fission yeast anillin Mid2 [142, 143]. However, the mechanism underlying this stabilization has yet to be discovered, as well as the physiological relevance of septin ring splitting. Indeed, BUD4 deletion causes mild cytokinesis defects that get more pronounced in sensitized mutant backgrounds [176].

The Rho1 GTPase, besides playing a pivotal role in CAR assembly [124](see below), has been recently shown to stabilize septins during their recruitment to the presumptive bud site through activation of its effector protein kinase $\mathrm{C}$ ( $\mathrm{Pkc1}$ ). Pkc1 in turn modulates the turnover at the bud neck of the F-BAR protein Syp1 through direct phosphorylation [177]. Syp1 is an endocytic protein that has been implicated in timely septin deposition and in stimulating septin ring dynamics through an unknown mechanism [177, 178]. Remarkably, Syp1 is recruited to the presumptive bud site in G1, at the same time as septins, and forms a ring that surrounds and is larger than the septin ring. After budding the Syp1 ring is thus found asymmetrically located on the mother side of the septin collar [177]. This peculiar spatial arrangement of Syp1 relative to septins is highly reminiscent of the coordination between secretion and endocytosis occurring during the establishment of cell polarity in G1, where endocytosis corrals at the membrane a vertex of active exocytosis for bud emergence [51]. Thus, altogether these data raise the possibility that timely accumulation of septins at the future bud site in late G1 might be facilitated by endocytic recycling. Interestingly, the EH domain-containing protein Ede1, which is a major partner of Syp1 for endocytosis $[179,180]$, has been recently implicated in cytokinesis [181]. 


\section{Other functions of the yeast septin ring}

Besides being necessary for cytokinesis, the budding yeast septin ring has been implicated in several other polarized processes. Some of them are intimately linked to the second main function of septins, in addition to scaffolding, as cortical barriers to prevent the free diffusion of membrane proteins between different compartments (reviewed in $[182,183])$. For instance, the septin ring hampers the diffusion to the mother cell of the mitotic exit regulator Lte1, normally localized in the bud cortex, thereby ensuring the proper coupling between correct spindle positioning and mitotic exit [184]. The septin ring also restricts to the bud the accumulation of the machinery responsible for the asymmetric localization of certain mRNAs [185, 186]. Additionally, the septin ring segregates some membrane proteins of the endoplasmic reticulum (ER) to a specific cell compartment, without influencing the distribution of ER luminal proteins that instead remain freely diffusible [187]. Finally, the septin ring contributes to proper spindle positioning early in mitosis [188] and promotes mitotic entry by scaffolding at the bud neck the machinery responsible for the degradation of the Wee1-like kinase Swe1, which inactivates mitotic cyclin-dependent kinases (CDKs) by inhibitory phosphorylation [189-192].

\section{Septin post-translational modifications}

Septins are targeted by many post-translational modifications, such as phosphorylation, acetylation, sumoylation and ubiquitination that likely modulate the state transitions of the septin ring during the cell cycle. Several protein kinases, such as Cla4, the Nim (never in mitosis)-related kinases Gin4, Kcc4 and Hsl1, as well as the Elm1 kinase, localize at the bud neck in a septin-dependent manner and promote septin collar formation and stabilization (reviewed in $[139,140,193])$. Specifically, Cla4 phosphorylates several septins in vitro [57] and is regulated by Elm1 [194], while Gin4 phosphorylates Shs1. Gin4 is phosphorylated and activated by Elm1, which together with Cla4 also promotes its recruitment to septins [190, 195, 196]. G1 cyclin-dependent kinases (CDKs) have also been implicated in septin phosphorylation, and CDK-dependent phosphorylation of Shs1 was shown to enhance its interaction with Gin4 [197, 198]. Although the extensive level of phosphorylation and the large number of kinases involved have hampered so far the functional dissection of this post-translational modification, as well as the assessment of the precise role of the Hsll and Kcc4 kinases in septin regulation, altogether septin phosphorylation seems to accompany septin ring stabilization. Consistently, the protein phosphatase PP2A bound to the Rts1 regulatory subunit reverses phosphorylation of at least Shs1 and contributes to timely septin disassembly after cytokinesis [199].

Several septins were found to be sumoylated in mitosis by the Siz1 and Siz2 Sumo-ligases [200, 201]. A mutant lacking the major sumoylation sites in $\mathrm{Cdc} 3, \mathrm{Cdc} 11$ and Shs1 displays prominent defects in septin ring disassembly at the end of mitosis. However, the lack of a similar phenotype in sizl siz2 double mutants or in $u b c 9$ temperaturesensitive mutant that affects the only Sumo-conjugating enzyme leaves open the possibility that the sumoylated lysines of septins might be targeted by other post-translational modifications, namely acetylation or ubiquitination [201].

The septins Cdc11 and Shs1 have been recently shown to be ubiquitinated by the Dma1 and Dma2 E3 ubiquitin ligases [202], which had been previously involved in septin ring stability [203, 204]. However, the role of septin ubiquitination remains to be established.

Finally, septin acetylation by the NuA4 and Esa1 lysine acetyltransferases was found to stabilize the septin collar [205]. Intriguingly, in mutants affecting septin acetylation septin complexes contain actin, suggesting that interaction of septins with the actin cytoskeleton might be deleterious for septin collar stability. Along the same line, in mammalian interphase cells, where septins colocalize with actin in long linear bundles or arcs, actin depolymerisation by cytochalasin D treatment leads to the formation of septin rings [206].

Although septin filaments are apolar and the septin collar is symmetric [207], several proteins that are recruited to the bud neck in a septin-dependent manner localize asymmetrically on the septin collar. For instance, the PP1 phosphatase Glc7 associated to its regulatory subunit Bni4, the F-BAR protein Syp1, the kinase Gin4 and the sumoligases Siz1 and Siz2 localize on the mother side of the septin collar, while the kinase Kcc4 is restricted to its bud side [201, 208, 209]. How this asymmetry is generated is unclear but it might rely on specific posttranslational modifications and in turn generate asymmetric septin modifications.

\section{Assembly of the actomyosin ring}

In many eukaryotic organisms, including budding yeast, cytokinesis involves a contractile actomyosin ring (CAR) made by the motor protein myosin II and actin filaments. The CAR assembles at the site of cell division and drives furrow ingression (reviewed by [210]). In S. cerevisiae the CAR is coordinated with and guides the formation of the primary septum, which involves the addition of a new cell wall between the dividing cells (see "Constriction of the actomyosin ring"). In the absence of a functional CAR 
budding yeast cells fail to invaginate the plasma membrane during cytokinesis but in some strain backgrounds they can eventually survive thanks to the formation of aberrant remedial septa [34, 211-213].

CAR assembly in budding yeast is a sequential order of events that starts in late G1 with the septin-dependent recruitment to the presumptive bud site of the single myosin type II heavy chain Myo1, along with its regulatory light chain Mlc2, [214, 215]. In mitosis, at a time when the essential myosin light chain Mlc1 appears at the bud neck, Myo1 interacts also with Mlc1. In telophase Mlc1 promotes the accumulation to the bud neck of the IQGAP protein Iqg1, which is in turn essential for recruiting filamentous actin (F actin) to the CAR, as well as for a second wave of Myo1 targeting to the neck that further increases its local levels [151, 214, 216-220].

The two formins Bni1 and Bnr1 are also essential for the engagement of $F$ actin at the CAR [112, 124], although their exact relationship with Iqg1 has not been established. Furthermore, formins have been recently shown to contribute to the accumulation of Mlc1 at the bud neck during cytokinesis [221], suggesting an additional mechanism by which they could participate in CAR assembly. In principle, many of the formin regulators described above (see "Rho GTPases in the establishment of cell polarity") could contribute to timely CAR assembly to various extents.

In $S$. pombe recruitment of formins to the medial cortex, where cytokinesis occurs, is partly mediated by the cytokinetic protein $\mathrm{Cdc15}$, which contains an F-BAR domain (F-BAR: 'FCH and BAR', where $\mathrm{FCH}=\mathrm{Fes}$ / CIP4 Homology and BAR = Bin-Amphiphysin-Rvs) to bind membranes and is a key regulator of CAR assembly and stability [222-226]. Its counterpart in budding yeast, called Hof1 (homologue of fifteen), interacts and partially constricts with the CAR but is thought to be dispensable for CAR function. Rather, it has been implicated in primary septum formation (see below) [81, 111, 112, 227, 228]. However, it has been recently reported that Hof 1 functions redundantly with the yeast amphiphysin Rvs167, which also contains a BAR domain, in promoting $F$ actin assembly at the CAR [229], suggesting that it might have a conserved role in CAR formation.

The precise function of the Mlc2/Myo1 complex early in the cell cycle is unknown, but has been proposed to stimulate the retrograde flow of cargos on actin cables [230]. In late G1 Myo1 recruitment to the neck depends on septins and the septin-binding protein Bni5 (see below) and is characterized by high turnover [34, 149, 152, 231]. As the cell cycle proceeds, Myo1 remains localized at the bud neck until $\mathrm{F}$ actin is recruited around anaphase to form the CAR [34, 35]. Shortly before cytokinesis Myo1 levels further increase at the bud neck through a mechanism that involves Mlc1 and Iqg1, and Myo1 becomes immobile at the neck where it acts as scaffold for the cytokinetic machinery [151, 231].

As already mentioned, the CAR consists of actin filaments nucleated by formins, which are in turn activated by the Rho1 GTPase [67, 112, 124]. Indeed, Rho1 is essential for assembly of the F actin ring [124], similar to RhoA in many eukaryotic organisms (reviewed in [232]). Rho1 is recruited to the division site through a major mechanism involving its GEFs (Rom1, Rom2 and Tus1) and a distinct backup mechanism depending on interaction between the $\mathrm{C}$ terminus of Rhol and acidic phospholipids [129]. Furthermore, the polo kinase Cdc5 is necessary for Rhol and Bnil localization at the bud neck, probably through direct phosphorylation of the GEFs Rom2 and Tus1 [130].

The exact arrangement of actin filaments inside the ring and the precise mechanism by which budding yeast formins contribute to the assembly/contraction of the cytokinetic ring have not been fully elucidated. In fission yeast it has been suggested that pre-existing actin cables might coalesce into the cytokinetic actin ring [233]. However, this model does not seem to apply to budding yeast, where cells with $\mathrm{F}$ actin rings are mostly devoid of actin cables, suggesting that the two structures compete with one another for formin-dependent polymerization [124].

Likely, both formins Bnr1 and Bnil can promote the assembly of the actin ring at the budding yeast bud neck since both form actin cables and localize at the bud neck, albeit in a mutually exclusive manner, during CAR assembly. Consistently, lack of either formin does not affect CAR formation, whereas inactivation of both, as well as inactivation of tropomyosins and profilin, disrupts actin recruitment to the CAR $[112,124]$.

Strikingly, at the onset of cytokinesis, concomitant with CAR contraction, Bnr1 leaves the bud neck through a process that appears to be linked to its dephosphorylation $[117,118]$, thus empowering Bnil as a prominent player for CAR contraction. Accordingly, in bnil null mutant cells the actin ring still forms but often fails to contract, while this is not the case for bnrl $\Delta$ mutants [112]. Thus, although Bnil and Bnr1 seem to play overlapping roles in actin ring formation, their coordinated interplay is important for proper ring contraction, possibly through the interaction with other polarized factors involved in cytokinesis.

The exact function of the IQGAP Iqg1 in CAR assembly has not been fully understood. Mammalian IQGAP can crosslink actin filaments [234] and has been proposed to act as scaffold for the actin assembly machinery [235, 236], while budding yeast Iqg1 can bind actin through its $\mathrm{N}$ terminal calponin-homology domain (CHD), suggesting that it might directly recruit actin to the CAR [217, 218]. Consistently, IQGI overexpression causes premature actin 
ring formation [217]. How Iqg1 and formins cooperate to assemble the actin ring is unclear. Mammalian IQGAP interacts physically with the formin Dial and is required for its proper localization [237]. Similarly, C. albicans Iqg1 associates with both formins Bni1 and Bnr1 and promotes efficient recruitment of Bnil to the bud neck [238]. Thus, Iqg1 might on one side organize actin filaments polymerized by formins and on the other favor efficient formin activity.

\section{Constriction of the actomyosin ring}

Shortly after its complete formation the CAR constricts (Fig. 5). In many organisms, CAR constriction during cytokinesis is thought to drive invagination of the overlying plasma membrane inward generating the force to cleave the cell in two (reviewed by [210]). In budding yeast CAR also drives membrane deposition through vesicle targeting and contributes to formation of the primary septum. The mechanism of CAR constriction has originally been inferred from that by which actomyosin generates force in the striated muscle, which stems from the sliding of bipolar myosin filaments along actin filaments that are organized in regular antiparallel arrays [239, 240]. However, this model does not seem to apply to budding yeast CAR. Indeed, Myo1 levels progressively decrease as the CAR constricts [162, 241], while they would be expected to remain constant if a sliding mechanism fully accounted for constriction. Furthermore, unlike in other organisms, the motor domain of Myo1 is not strictly required for CAR constriction and cytokinesis [151, 242, 243], while the rest of the protein is essential in most strain backgrounds and necessary for actin assembly in the CAR [34, 213, 244]. In agreement with these observations, CAR contraction in $S$. cerevisiae has been recently shown to be mainly driven by actin depolymerisation promoted by the cofilin Cof1. Actin depolymerisation by Cof1 synergizes with the motor activity of Myo1 to promote fast CAR constriction, with the latter mechanism playing a less prominent role than the former [243]. Since the action of cofilin can be stimulated by actin crosslinking to generate contractile stress [245], the IQGAP Iqg1 has been proposed to play such a role during yeast cytokinesis [243]. Consistently, deletion of the $\mathrm{C}$ terminal GTPase-activating protein-related domain of Iqg1 prevents CAR constriction without affecting CAR assembly [218], while the phosphorylation-deficient mutants of IQGI slow down CAR constriction, while advancing CAR formation [238, 246]. Interestingly, although Iqg1 is necessary for CAR assembly and constriction, its ubiquitin-dependent degradation mediated by the anaphase-promoting complex is important for CAR disassembly after cytokinesis [241].

Around the time of CAR constriction the myosin V Myo2, which transports post-Golgi vesicles along actin cables, and the exocyst complex, which tethers secretory vesicles to the plasma membrane, get recruited to the CAR to promote delivery of membrane and essential cargoes to the division site $[120,151,162,199,231]$. The essential myosin light chain Mlc1 is required for Myo2 tethering to the bud neck [247], thereby coordinating CAR formation with membrane trafficking. Remarkably, interfering with membrane traffic at the bud neck through mutations affecting Myo2 or exocyst subunits leads to CAR destabilization during constriction, without affecting CAR assembly [120]. Similarly, loss of the chitin synthase Chs2, which is required for primary septum formation and is transported to the bud neck through Myo2- and exocystmediated secretion (see below), affects the stability of the CAR during contraction [120, 212], suggesting that CAR

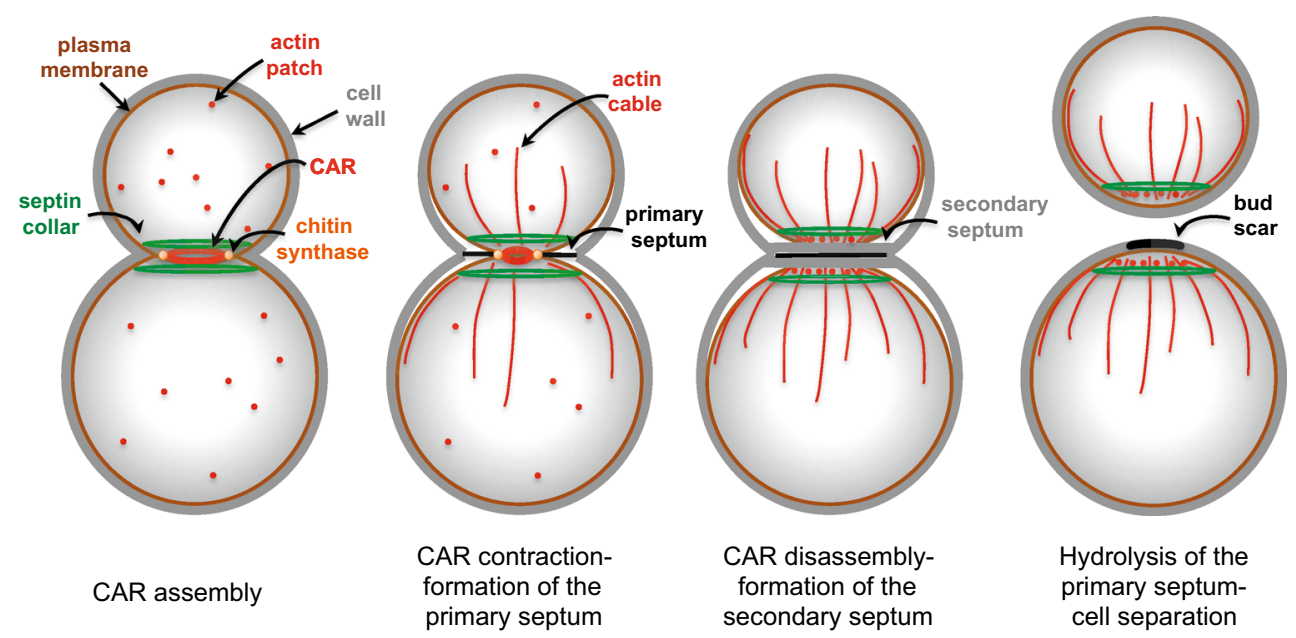

Fig. 5 The septin ring during budding yeast cell cycle. Sequential stages of septin organization during the cell cycle of budding yeast 
constriction, secretion and septation are intimately connected processes (Fig. 5).

\section{Septum formation}

Contractile actomyosin ring constriction in budding yeast is coupled to the centripetal deposit of a primary septum that physically separates the two daughter cells. The primary septum is a chitin disk deposited by the action of the chitin synthase 2 (Chs2, Fig. 5). Chs2 is synthesized in G2/ $\mathrm{M}$ and accumulates in the endoplasmic reticulum (ER) until the end of mitosis [248]. Inactivation of mitotic CDKs or Chs2 dephosphorylation by the Cdc14 phosphatase triggers the translocation of the chitin synthase Chs 2 from the ER to the bud neck [249-251] (see also "The mitotic exit network"). As mentioned above, Chs2 is a cargo of the exocyst complex and delivered to the bud neck through Myo2-dependent transport along actin cables. Then, Chs2 persists at the bud neck to form the primary septum in coordination with CAR contraction [120, 212, 248] (Fig. 5). Once this process is accomplished, Chs 2 is removed from the neck by endocytosis and transferred to the vacuole for degradation [252].

The F-BAR protein Hof1 forms a ternary complex with the cytokinetic proteins Inn1 and Cyk3 to couple CAR contraction with membrane ingression and primary septum deposition. Mutants affecting the Hof1-Inn1-Cyk3 complex exhibit various degrees of cytokinesis defects and Inn1, but not Hof 1 and Cyk3, is essential for cell viability [111, 112, 227, 253-257]. Furthermore, overexpression of $H O F 1$ and $C Y K 3$ efficiently rescues the cytokinetic defects of iqgl mutant cells without restoring a CAR [254]. The Hof1-Inn1-Cyk3 complex is thought to be mainly involved in cytokinesis by promoting primary septum formation, most likely by activating the chitin synthase Chs2 [181, 251, 255, 258]. Consistently, Hof1 interacts physically with Chs2 and stabilizes it at the bud neck during CAR constriction, while overexpression of $\mathrm{HOF} 1$ or $C Y K 3$ rescues the cytokinetic defects of hypomorphic, but not null, chs 2 mutants [111, 256]. In addition, mutants affecting the Hof1-Inn1-Cyk3 complex fail to undergo centripetal and symmetric CAR contraction, resulting in CAR destabilization during constriction similar to chs2 mutant cells [120, 212, 227, 228, 257].

Shortly after the primary septum starts being assembled, cells deposit a secondary septum composed of glucans (polymers of glucose) and mannoproteins (heavily glycosylated cell wall proteins bearing abundant mannose sugars) on each side of the chitin disk (Fig. 5). Synthesis of 1,3-beta-linked glucans, which confer most of the rigidity to the yeast cell wall, is accounted for by the redundant 1,3beta-glucan synthases Fks1 and Fks2, which in turn are effectors of the Rhol GTPase (reviewed in [259]), while synthesis of mannoproteins requires a mannosyltransferase complex (reviewed in [260]. Formation of the secondary septum also involves directed secretion [199]. Strikingly, actin cables are oriented toward the bud neck and actin patches cluster at the bud neck during this process enforcing polarized vesicle traffic (Fig. 5). Finally, chitin synthase 3 (Chs3) also contributes to deposition of the secondary septum [261]. In contrast to deletion of $\mathrm{CHS} 2$, which abolishes primary septum formation and causes severe cytokinesis failure, deletion of $\mathrm{CHS3}$, either alone or in combination with that of the third chitin synthase Chs1, does not cause obvious cytokinetic defects [251, 261, 262]. However, chs 2 mutant cells can survive thanks to the deposition of aberrant remedial septa mostly made by Chs 3 that fill up the intercellular space [261, 263]. Remarkably, remedial septa are also built in the absence of CAR assembly, such as in myol $\Delta$ mutants, and therefore represent a major backup cytokinetic mechanism and a resource for cells to rapidly adapt to these adverse conditions [211].

Upon completion of a primary and secondary septum, the cell wall between mother and daughter cell is degraded by hydrolytic enzymes, such as the chitinase Cts1 [264] and several glucanases, including Dse4 and Egt2 [265, 266], thereby allowing cell separation (Fig. 5). Transcription of the genes responsible for cell wall digestion is driven by the Ace 2 transcription factor and occurs only at the $M$ to $G 1$ transition of the cell cycle [267], thereby contributing to ensure proper timing of cell separation. Strikingly, the Ace2-dependent transcriptional program driving expression of most hydrolytic enzymes is restricted to the bud, thus explaining why after cell division a birth scar of undigested cell wall is only visible in the mother cells [15].

\section{The mitotic exit network}

The budding yeast Mitotic Exit Network (MEN), is an essential kinase cascade that is similarly organized to the fission yeast Septation Initiation Network and the metazoan Hippo pathway (reviewed in [268-270]). MEN plays a crucial role in actin repolarization at the end of mitosis, as well as in cytokinesis, and comprises an upstream GTPase (Tem1), its effector Cdc15 kinase, the Mob1-Dbf2 kinase and the $\mathrm{Cdc} 14$ phosphatase. The polo kinase $\mathrm{Cdc} 5$ activates Tem1 by dampening the activity of the two component GTPase-activating protein Bub2-Bfa1, which keeps a large pool of Tem1 inactive until telophase (reviewed in [271]). Other upstream regulators, such as the polo kinase $\mathrm{Cdc5}$, the bud-localized cortical protein Lte1 and the mother cellspecific Kin 4 kinase, modulate Tem 1 activation especially in relation to spindle positioning and nuclear division 


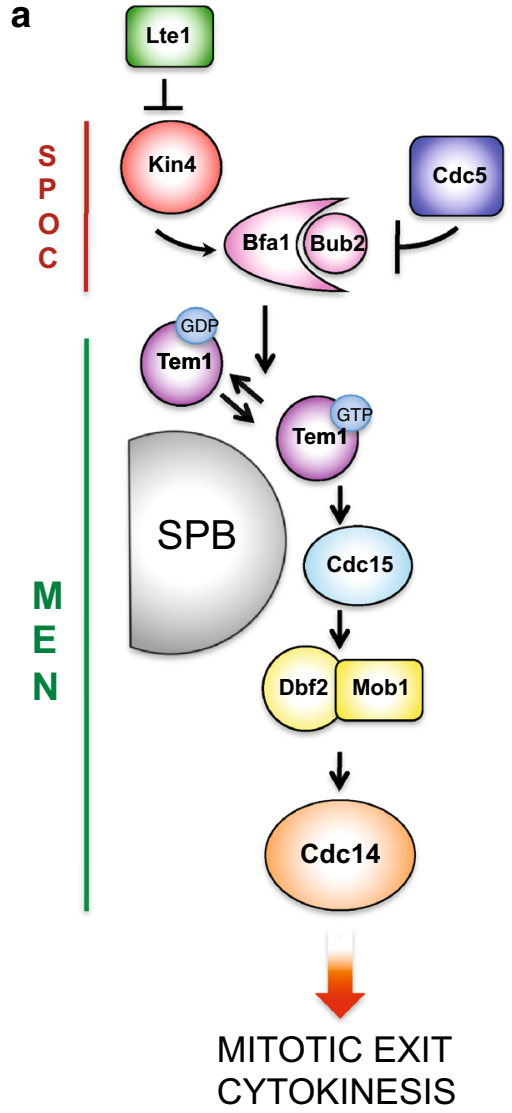

Fig. 6 The mitotic exit network (MEN) and its regulation by the spindle position checkpoint (SPOC). a MEN signaling takes place mostly at SPBs, where the GTPase Tem1 in its active GTP-bound state promotes recruitment and activation of the $\mathrm{Cdc} 15$ protein kinase, which in turn recruits the Dbf2-Mob1 kinase complex that ultimately activates the $\mathrm{Cdc} 14$ phosphatase, thereby triggering mitotic exit and cytokinesis. Tem1 is kept inactive by the GTPase-activating protein Bfa1-Bub2 that can be inhibited by the polo kinase Cdc5, whose

(Fig. 6a). Tem1 and MEN are indeed the targets of the Spindle Position Checkpoint (SPOC), which keeps Tem1 inhibited until the spindle elongates properly along the mother-bud polarity axis in anaphase, thereby preventing mitotic exit and cytokinesis in case of spindle misalignment (reviewed in [12, 13]; Fig. 6b). Intriguingly, proper mitochondrial inheritance from the mother to the daughter cells is required for the function of MEN in cytokinesis [272], suggesting that budding yeast cells keep MEN activity in standby until a balanced set of chromosomes and organelles have been segregated to the bud.

The core MEN actors are thought to work in a linear cascade (Tem1 > Cdc15 > Mob-Dbf $>$ Cdc14), although feedback controls by Cdc14 on various MEN components have been discovered [273-275]. MEN signaling for mitotic exit (i.e., inactivation of mitotic CDKs) occurs at spindle pole bodies (SPBs, i.e., the budding yeast microtubule-organizing centers) by recruitment of MEN b

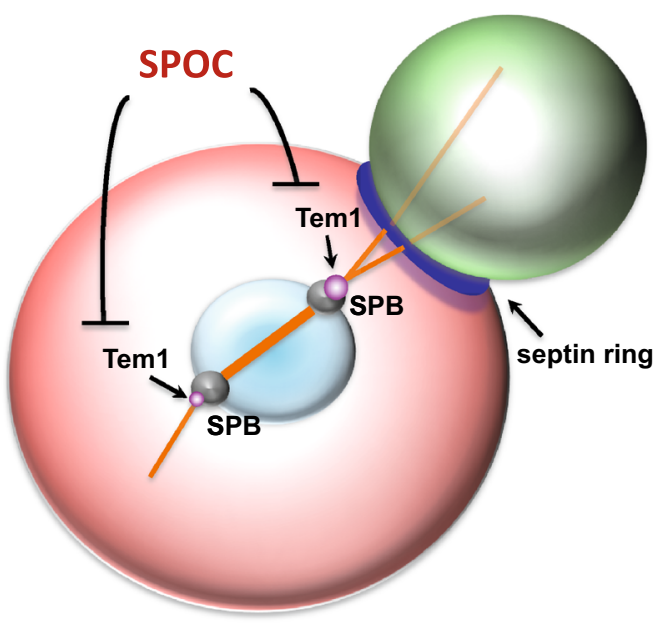

activity is counteracted by the kinase Kin 4 in the mother cell. In turn, the Lte1 protein, which is localized specifically in the bud, restrains Kin4 in the mother compartment. b The MEN inhibitor Kin4 and the MEN activator Lte1 are spatially segregated in the mother and bud compartment, respectively (Kin4 red, Lte1 green). As long as an SPB has not moved into the bud, Tem1 and MEN are kept inactive, thereby coupling spindle positioning and nuclear division with mitotic exit

components to the SPB scaffold Nud1 (reviewed in [268, 276]; Fig. 6).

The Cdc14 phosphatase promotes mitotic exit in two ways, i.e., by inhibiting mitotic cyclinB-CDKs and by reversing CDK-driven phosphorylation events [277]. MEN is strictly required for its full activation in telophase (reviewed in [278]). Thus, one reason for MEN being involved in cytokinesis is linked to inactivation of CDKs, which otherwise prevent cytokinesis in many eukaryotic systems (reviewed in [8]). For instance, in budding yeast CDK inactivation in telophase is required for actin repolarization and targeted secretion at the bud neck [42, 120]. Many MEN proteins, however, relocalize from SPBs to the bud neck upon mitotic exit, suggesting the existence of additional direct roles in cytokinesis regulation [130, 279-285]. This is indeed the case. Although to date the list of MEN-regulated cytokinesis proteins is likely incomplete, we know several examples of 
cytokinesis factors that are phosphorylated by MEN kinases or dephosphorylated by Cdc14 (see below). Furthermore, inactivation of MEN proteins in conditions that allow mitotic exit prevents CAR contraction [161, 250]. It is interesting to note that the fission yeast Septation Initiation Network, while being similarly organized to the MEN and involving orthologous proteins, is specifically required for cytokinesis and dispensable for mitotic exit $[268,286]$.

Although MEN has been clearly involved in CAR constriction and cytokinesis (see below), its role in CAR assembly is controversial. Some MEN mutants have been reported to fail recruiting $\mathrm{F}$ actin to the $\mathrm{CAR}$ at restrictive temperature [35, 246, 280, 287], while others were shown to proficiently assemble an apparently functional actin ring $[112,130,282]$. Since activation of the Cdc14 phosphatase is required for actin ring formation [246], it is quite surprising that the upstream MEN factors are dispensable for this process. Likely, the ability of some MEN mutants to assemble a functional CAR is ascribable to an incomplete inactivation of the corresponding MEN proteins.

An important target of Cdc14 in CAR assembly is the IQGAP Iqg1 (see "The septin ring"). Iqg1 is phosphorylated in vivo by mitotic CDKs both in $S$. cerevisiae [288, 289] and in C. albicans [238] and is dephosphorylated by Cdc14 [246]. Mutating the CDK-dependent phosphorylation sites of Iqg1 to non-phosphorylatable alanines leads to premature CAR assembly before anaphase, thus recapitulating the phenotype of cells that either overexpress CDC14 or have reduced levels of mitotic CDKs [238, 246, 290, 291]. Additionally, expression of non-phosphorylatable Iqg1 rescues the inability of $c d c 14$ mutant cells to assemble the $\mathrm{F}$ actin ring at restrictive temperature [246], suggesting that Iqg1 is a crucial MEN target in this process.

The chitin synthase Chs 2 is phosphorylated by mitotic CDKs and dephosphorylated by Cdc14 to promote its timely relocalization from the ER to the bud neck [249]. Cdc14 has also been shown to interact with and dephosphorylate both formins Bni1 and Bnr1. In $c d c 14$ and $c d c 15$ mutants Bnil fails to localize to the bud neck, whereas CDC14 overexpression in metaphase displaces Bnr1 from the CAR while recruiting Bnil [117]. Furthermore, Inn1 recruitment to the neck and activity is likely regulated by CDK-dependent phosphorylation and subsequent dephosphorylation mediated by Cdc14 [181, 250, 255], although the exact mechanism underlying this control remains to be defined. Finally, high CDK activity inhibits the daughterspecific transcriptional program responsible for the expression of the septum-degrading enzymes at the end of cytokinesis through phosphorylation of the transcription factor Ace2, while Cdc14 reverses inhibition [15, 16, 267,
292, 293]. Additional potential cytokinesis targets of mitotic CDKs and/or Cdc14 have been recently identified and hold promises for exciting discoveries in the future $[117,181]$.

Although activation of the Cdc14 phosphatase appears to be the main function of MEN in cytokinesis [181, 291], upstream MEN factors might contribute directly to this process. For instance, the MEN kinase Dbf2 directly phosphorylates Chs 2 and likely stimulates its removal from the CAR by endocytosis [251]. Furthermore, Dbf2-dependent phosphorylation promotes activation of the Chs2 regulatory complex Hof1-Inn1-Cyk3 in several ways. On one hand, MEN contributes to the efficient recruitment of Chs2, Hof1, Inn1 and Cyk3 to the bud neck even independently of mitotic exit [250]. On the other, Hof1 phosphorylation by Dbf2 dissociates it from the septin ring and relocalizes it to the CAR [228].

\section{Concluding remarks}

The last 20 years have witnessed a blooming of papers addressing the mechanisms that regulate cytokinesis. The budding yeast $S$. cerevisiae remains an outstanding model system to study this process, as many of the basic principles underlying cytokinesis are conserved in more complex eukaryotes.

In spite of cutting-edge technologies that have considerably improved the resolution of cytokinetic events and the enormous efforts by researchers in the field, many important questions await an answer, such as how precisely the CAR is organized and what contributes to its contraction, how formins promote CAR assembly, how CAR constriction is coupled to membrane addition, what drives the splitting of the septin ring, which are the critical targets of mitotic CDKs and MEN in cell division, and so forth.

One major obstacle to the progress of our knowledge in this field is the redundancy and intertwinings of cytokinetic pathways and proteins involved, which often makes the contribution of each hard to assess. Nevertheless, we can therefore expect in the years to come exciting discoveries that will shed light on such a fascinating and intricate process providing, hopefully, a complete and detailed picture of cytokinesis.

Acknowledgments We apologize to all the authors whose works could not be cited here due to the vastity of the subject. We thank M. Granata, L. Merlini, G. Rancati, S. Rincon, A. Sanchez-Diaz and M. Segal for critical reading of the manuscript. Work in S. Piatti's lab is supported by the Fondation pour la Recherche Médicale (Grant DEQ 20150331740), the Ligue Nationale contre le Cancer and the Fondation ARC (Grant PJA 20141201926). 
Open Access This article is distributed under the terms of the Creative Commons Attribution 4.0 International License (http:// creativecommons.org/licenses/by/4.0/), which permits unrestricted use, distribution, and reproduction in any medium, provided you give appropriate credit to the original author(s) and the source, provide a link to the Creative Commons license, and indicate if changes were made.

\section{References}

1. Chia W, Somers WG, Wang H (2008) Drosophila neuroblast asymmetric divisions: cell cycle regulators, asymmetric protein localization, and tumorigenesis. J Cell Biol 180:267-272

2. Doe CQ (2008) Neural stem cells: balancing self-renewal with differentiation. Development 135(9):1575-1587

3. Knoblich JA (2008) Mechanisms of asymmetric stem cell division. Cell 132(4):583-597

4. Gonzalez C (2007) Spindle orientation, asymmetric division and tumour suppression in Drosophila stem cells. Nat Rev Genet 8(6):462-472

5. Morrison SJ, Kimble J (2006) Asymmetric and symmetric stemcell divisions in development and cancer. Nature 441(7097):1068-1074

6. Neumuller RA, Knoblich JA (2009) Dividing cellular asymmetry: asymmetric cell division and its implications for stem cells and cancer. Genes Dev 23(23):2675-2699

7. Siller KH, Doe CQ (2009) Spindle orientation during asymmetric cell division. Nat Cell Biol 11(4):365-374

8. Barr FA, Gruneberg U (2007) Cytokinesis: placing and making the final cut. Cell 131(5):847-860

9. Bringmann H, Hyman AA (2005) A cytokinesis furrow is positioned by two consecutive signals. Nature 436(7051):731-734

10. Dechant R, Glotzer M (2003) Centrosome separation and central spindle assembly act in redundant pathways that regulate microtubule density and trigger cleavage furrow formation. Dev Cell 4(3):333-344

11. Oliferenko S, Chew TG, Balasubramanian MK (2009) Positioning cytokinesis. Genes Dev 23(6):660-674

12. Caydasi AK, Ibrahim B, Pereira G (2010) Monitoring spindle orientation: spindle position checkpoint in charge. Cell Div 5:28

13. Fraschini R, Venturetti M, Chiroli E, Piatti S (2008) The spindle position checkpoint: how to deal with spindle misalignment during asymmetric cell division in budding yeast. Biochem Soc Trans 36(Pt 3):416-420

14. Mortimer RK, Johnston JR (1959) Life span of individual yeast cells. Nature 183(4677):1751-1752

15. Colman-Lerner A, Chin TE, Brent R (2001) Yeast Cbk1 and Mob2 activate daughter-specific genetic programs to induce asymmetric cell fates. Cell 107(6):739-750

16. Mazanka E, Alexander J, Yeh BJ, Charoenpong P, Lowery DM, Yaffe M, Weiss EL (2008) The NDR/LATS family kinase Cbk1 directly controls transcriptional asymmetry. PLoS Biol 6(8): 203

17. Nelson WJ (2003) Adaptation of core mechanisms to generate cell polarity. Nature 422(6933):766-774

18. Park HO, Bi E (2007) Central roles of small GTPases in the development of cell polarity in yeast and beyond. Microbiol Mol Biol Rev 71(1):48-96

19. Macara IG, McCaffrey L (2013) Cell polarity in morphogenesis and metastasis. Philos Trans R Soc Lond B Biol Sci 368(1629):20130012
20. Muthuswamy SK, Xue B (2012) Cell polarity as a regulator of cancer cell behavior plasticity. Annu Rev Cell Dev Biol 28:599-625

21. Pruyne D, Bretscher A (2000) Polarization of cell growth in yeast. J Cell Sci 113(Pt 4):571-585

22. Pruyne D, Bretscher A (2000) Polarization of cell growth in yeast. I. Establishment and maintenance of polarity states. J Cell Sci 113(3):365-375

23. Martin SG, Arkowitz RA (2014) Cell polarization in budding and fission yeasts. FEMS Microbiol Rev 38(2):228-253

24. Moseley JB, Goode BL (2006) The yeast actin cytoskeleton: from cellular function to biochemical mechanism. Microbiol Mol Biol Rev 70(3):605-645

25. Engqvist-Goldstein AE, Drubin DG (2003) Actin assembly and endocytosis: from yeast to mammals. Annu Rev Cell Dev Biol 19:287-332

26. Goode BL, Eskin JA, Wendland B (2015) Actin and endocytosis in budding yeast. Genetics 199(2):315-358

27. Smythe E, Ayscough KR (2006) Actin regulation in endocytosis. J Cell Sci 119(Pt 22):4589-4598

28. Adams AE, Pringle JR (1984) Relationship of actin and tubulin distribution to bud growth in wild-type and morphogeneticmutant Saccharomyces cerevisiae. J Cell Biol 98(3):934-945

29. Pruyne DW, Schott DH, Bretscher A (1998) Tropomyosincontaining actin cables direct the Myo2p-dependent polarized delivery of secretory vesicles in budding yeast. J Cell Biol 143(7):1931-1945

30. Kilmartin JV, Adams AE (1984) Structural rearrangements of tubulin and actin during the cell cycle of the yeast Saccharomyces. J Cell Biol 98(3):922-933

31. Sagot I, Klee SK, Pellman D (2002) Yeast formins regulate cell polarity by controlling the assembly of actin cables. Nat Cell Biol 4(1):42-50

32. Sagot I, Rodal AA, Moseley J, Goode BL, Pellman D (2002) An actin nucleation mechanism mediated by Bnil and profilin. Nat Cell Biol 4(8):626-631

33. Zahner JE, Harkins HA, Pringle JR (1996) Genetic analysis of the bipolar pattern of bud site selection in the yeast Saccharomyces cerevisiae. Mol Cell Biol 16(4):1857-1870

34. Bi E, Maddox P, Lew DJ, Salmon ED, McMillan JN, Yeh E, Pringle JR (1998) Involvement of an actomyosin contractile ring in Saccharomyces cerevisiae cytokinesis. J Cell Biol 142(5):1301-1312

35. Lippincott J, Li R (1998) Sequential assembly of myosin II, an IQGAP-like protein, and filamentous actin to a ring structure involved in budding yeast cytokinesis. J Cell Biol 140(2):355-366

36. Chant J, Herskowitz I (1991) Genetic control of bud site selection in yeast by a set of gene products that constitute a morphogenetic pathway. Cell 65(7):1203-1212

37. Park HO, Bi E, Pringle JR, Herskowitz I (1997) Two active states of the Ras-related Bud1/Rsr1 protein bind to different effectors to determine yeast cell polarity. Proc Natl Acad Sci USA 94(9):4463-4468

38. Park HO, Chant J, Herskowitz I (1993) BUD2 encodes a GTPase-activating protein for Bud1/Rsr1 necessary for proper bud-site selection in yeast. Nature 365(6443):269-274

39. Bi E, Park HO (2012) Cell polarization and cytokinesis in budding yeast. Genetics 191(2):347-387

40. Casamayor A, Snyder M (2002) Bud-site selection and cell polarity in budding yeast. Curr Opin Microbiol 5(2):179-186

41. Howell AS, Lew DJ (2012) Morphogenesis and the cell cycle. Genetics 190(1):51-77

42. Lew DJ, Reed SI (1993) Morphogenesis in the yeast cell cycle: regulation by Cdc28 and cyclins. J Cell Biol 120(6):1305-1320 
43. Bourne HR, Sanders DA, McCormick F (1990) The GTPase superfamily: a conserved switch for diverse cell functions. Nature 348(6297):125-132

44. Vetter IR, Wittinghofer A (2001) The guanine nucleotidebinding switch in three dimensions. Science 294(5545):1299-1304

45. Bourne HR, Sanders DA, McCormick F (1991) The GTPase superfamily: conserved structure and molecular mechanism. Nature 349(6305):117-127

46. Schweins T, Wittinghofer A (1994) GTP-binding proteins. Structures, interactions and relationships. Curr Biol 4(6):547-550

47. Dransart E, Olofsson B, Cherfils J (2005) RhoGDIs revisited: novel roles in Rho regulation. Traffic 6(11):957-966

48. Bose I, Irazoqui JE, Moskow JJ, Bardes ES, Zyla TR, Lew DJ (2001) Assembly of scaffold-mediated complexes containing Cdc42p, the exchange factor Cdc24p, and the effector Cla $4 p$ required for cell cycle-regulated phosphorylation of Cdc24p. J Biol Chem 276(10):7176-7186

49. Howell AS, Savage NS, Johnson SA, Bose I, Wagner AW, Zyla TR, Nijhout HF, Reed MC, Goryachev AB, Lew DJ (2009) Singularity in polarization: rewiring yeast cells to make two buds. Cell 139(4):731-743

50. Kozubowski L, Saito K, Johnson JM, Howell AS, Zyla TR, Lew DJ (2008) Symmetry-breaking polarization driven by a Cdc42p GEF-PAK complex. Curr Biol 18(22):1719-1726

51. Jose M, Tollis S, Nair D, Sibarita JB, McCusker D (2013) Robust polarity establishment occurs via an endocytosis-based cortical corralling mechanism. J Cell Biol 200(4):407-418

52. Slaughter BD, Das A, Schwartz JW, Rubinstein B, Li R (2009) Dual modes of cdc42 recycling fine-tune polarized morphogenesis. Dev Cell 17(6):823-835

53. Cvrckova F, De Virgilio C, Manser E, Pringle JR, Nasmyth K (1995) Ste20-like protein kinases are required for normal localization of cell growth and for cytokinesis in budding yeast. Genes Dev 9(15):1817-1830

54. Goehring AS, Mitchell DA, Tong AH, Keniry ME, Boone C, Sprague GF Jr (2003) Synthetic lethal analysis implicates Ste20p, a p21-activated protein kinase, in polarisome activation. Mol Biol Cell 14(4):1501-1516

55. Holly SP, Blumer KJ (1999) PAK-family kinases regulate cell and actin polarization throughout the cell cycle of Saccharomyces cerevisiae. J Cell Biol 147(4):845-856

56. Kadota J, Yamamoto T, Yoshiuchi S, Bi E, Tanaka K (2004) Septin ring assembly requires concerted action of polarisome components, a PAK kinase Cla4p, and the actin cytoskeleton in Saccharomyces cerevisiae. Mol Biol Cell 15(12):5329-5345

57. Versele M, Thorner J (2004) Septin collar formation in budding yeast requires GTP binding and direct phosphorylation by the PAK, Cla4. J Cell Biol 164(5):701-715

58. Weiss EL, Bishop AC, Shokat KM, Drubin DG (2000) Chemical genetic analysis of the budding-yeast p21-activated kinase cla4p [In Process Citation]. Nat Cell Biol 2(10):677-685

59. Dong Y, Pruyne D, Bretscher A (2003) Formin-dependent actin assembly is regulated by distinct modes of Rho signaling in yeast. J Cell Biol 161(6):1081-1092

60. Brown JL, Jaquenoud M, Gulli MP, Chant J, Peter M (1997) Novel Cdc42-binding proteins Gic1 and Gic2 control cell polarity in yeast. Genes Dev 11(22):2972-2982

61. Chen GC, Kim YJ, Chan CS (1997) The Cdc42 GTPase-associated proteins Gic1 and Gic2 are required for polarized cell growth in Saccharomyces cerevisiae. Genes Dev 11(22):2958-2971

62. Chen H, Kuo CC, Kang H, Howell AS, Zyla TR, Jin M, Lew DJ (2012) Cdc42p regulation of the yeast formin Bnilp mediated by the effector Gic2p. Mol Biol Cell 23(19):3814-3826
63. Iwase M, Luo J, Nagaraj S, Longtine M, Kim HB, Haarer BK, Caruso C, Tong Z, Pringle JR, Bi E (2006) Role of a Cdc42p effector pathway in recruitment of the yeast septins to the presumptive bud site. Mol Biol Cell 17(3):1110-1125

64. Zhang X, Bi E, Novick P, Du L, Kozminski KG, Lipschutz JH, Guo W (2001) Cdc42 interacts with the exocyst and regulates polarized secretion. J Biol Chem 276(50):46745-46750

65. Zhang X, Orlando K, He B, Xi F, Zhang J, Zajac A, Guo W (2008) Membrane association and functional regulation of Sec3 by phospholipids and Cdc42. J Cell Biol 180(1):145-158

66. Imamura $H$, Tanaka $K$, Hihara $T$, Umikawa $M$, Kamei $T$, Takahashi K, Sasaki T, Takai Y (1997) Bnilp and Bnrlp: downstream targets of the Rho family small G-proteins which interact with profilin and regulate actin cytoskeleton in Saccharomyces cerevisiae. EMBO J 16(10):2745-2755

67. Kohno H, Tanaka K, Mino A, Umikawa M, Imamura H, Fujiwara T, Fujita Y, Hotta K, Qadota H, Watanabe T, Ohya Y, Takai Y (1996) Bnilp implicated in cytoskeletal control is a putative target of Rholp small GTP binding protein in Saccharomyces cerevisiae. EMBO J 15(22):6060-6068

68. Qadota H, Python CP, Inoue SB, Arisawa M, Anraku Y, Zheng Y, Watanabe T, Levin DE, Ohya Y (1996) Identification of yeast Rho1p GTPase as a regulatory subunit of 1,3-beta-glucan synthase. Science 272(5259):279-281

69. Kamada Y, Qadota H, Python CP, Anraku Y, Ohya Y, Levin DE (1996) Activation of yeast protein kinase C by Rhol GTPase. J Biol Chem 271(16):9193-9196

70. Nonaka H, Tanaka K, Hirano H, Fujiwara T, Kohno H, Umikawa M, Mino A, Takai Y (1995) A downstream target of RHO1 small GTP-binding protein is PKC1, a homolog of protein kinase $\mathrm{C}$, which leads to activation of the MAP kinase cascade in Saccharomyces cerevisiae. EMBO J 14(23):5931-5938

71. Guo W, Tamanoi F, Novick P (2001) Spatial regulation of the exocyst complex by Rho1 GTPase. Nat Cell Biol 3(4):353-360

72. Chalkia D, Nikolaidis N, Makalowski W, Klein J, Nei M (2008) Origins and evolution of the formin multigene family that is involved in the formation of actin filaments. Mol Biol Evol 25(12):2717-2733

73. Chesarone MA, DuPage AG, Goode BL (2010) Unleashing formins to remodel the actin and microtubule cytoskeletons. Nat Rev Mol Cell Biol 11(1):62-74

74. Evangelista M, Blundell K, Longtine MS, Chow CJ, Adames N, Pringle JR, Peter M, Boone C (1997) Bnilp, a yeast formin linking cdc42p and the actin cytoskeleton during polarized morphogenesis. Science 276(5309):118-122

75. Evangelista M, Pruyne D, Amberg DC, Boone C, Bretscher A (2002) Formins direct Arp2/3-independent actin filament assembly to polarize cell growth in yeast. Nat Cell Biol 4(3):260-269

76. Pruyne D, Gao L, Bi E, Bretscher A (2004) Stable and dynamic axes of polarity use distinct formin isoforms in budding yeast. Mol Biol Cell 15(11):4971-4989

77. Buttery SM, Yoshida S, Pellman D (2007) Yeast formins Bni1 and Bnr1 utilize different modes of cortical interaction during the assembly of actin cables. Mol Biol Cell 18(5):1826-1838

78. Delgehyr N, Lopes CS, Moir CA, Huisman SM, Segal M (2008) Dissecting the involvement of formins in Bud6p-mediated cortical capture of microtubules in S. cerevisiae. J Cell Sci $121(\mathrm{Pt}$ 22):3803-3814

79. Moseley JB, Goode BL (2005) Differential activities and regulation of Saccharomyces cerevisiae formin proteins Bnil and Bnr1 by Bud6. J Biol Chem 280(30):28023-28033

80. Wen KK, Rubenstein PA (2009) Differential regulation of actin polymerization and structure by yeast formin isoforms. J Biol Chem 284(25):16776-16783 
81. Kamei T, Tanaka K, Hihara T, Umikawa M, Imamura H, Kikyo M, Ozaki K, Takai Y (1998) Interaction of Bnrlp with a novel Src homology 3 domain-containing Hoflp. Implication in cytokinesis in Saccharomyces cerevisiae. J Biol Chem 273(43):28341-28345

82. Ozaki-Kuroda K, Yamamoto Y, Nohara H, Kinoshita M, Fujiwara T, Irie K, Takai Y (2001) Dynamic localization and function of Bnilp at the sites of directed growth in Saccharomyces cerevisiae. Mol Cell Biol 21(3):827-839

83. Fujiwara T, Tanaka K, Mino A, Kikyo M, Takahashi K, Shimizu K, Takai Y (1998) Rho1p-Bni1p-Spa2p interactions: implication in localization of Bnilp at the bud site and regulation of the actin cytoskeleton in Saccharomyces cerevisiae. Mol Biol Cell 9(5):1221-1233

84. Sheu YJ, Santos B, Fortin N, Costigan C, Snyder M (1998) Spa2p interacts with cell polarity proteins and signaling components involved in yeast cell morphogenesis. Mol Cell Biol 18(7):4053-4069

85. Graziano BR, DuPage AG, Michelot A, Breitsprecher D, Moseley JB, Sagot I, Blanchoin L, Goode BL (2011) Mechanism and cellular function of Bud6 as an actin nucleationpromoting factor. Mol Biol Cell 22(21):4016-4028. doi:10. 1091/mbc.E11-05-0404

86. Graziano BR, Jonasson EM, Pullen JG, Gould CJ, Goode BL (2013) Ligand-induced activation of a formin-NPF pair leads to collaborative actin nucleation. J Cell Biol 201(4):595-611

87. Moseley JB, Sagot I, Manning AL, Xu Y, Eck MJ, Pellman D, Goode BL (2004) A conserved mechanism for Bni1- and mDia1-induced actin assembly and dual regulation of Bnil by Bud6 and profilin. Mol Biol Cell 15(2):896-907

88. Xu Y, Moseley JB, Sagot I, Poy F, Pellman D, Goode BL, Eck MJ (2004) Crystal structures of a formin homology-2 domain reveal a tethered dimer architecture. Cell 116(5):711-723

89. Pring M, Evangelista M, Boone C, Yang C, Zigmond SH (2003) Mechanism of formin-induced nucleation of actin filaments. Biochemistry 42(2):486-496

90. Castrillon DH, Wasserman SA (1994) Diaphanous is required for cytokinesis in Drosophila and shares domains of similarity with the products of the limb deformity gene. Development 120(12):3367-3377

91. Alberts AS (2001) Identification of a carboxyl-terminal diaphanous-related formin homology protein autoregulatory domain. J Biol Chem 276(4):2824-2830

92. Li F, Higgs HN (2005) Dissecting requirements for auto-inhibition of actin nucleation by the formin, mDial. J Biol Chem 280(8):6986-6992

93. Gould CJ, Maiti S, Michelot A, Graziano BR, Blanchoin L, Goode BL (2011) The formin DAD domain plays dual roles in autoinhibition and actin nucleation. Curr Biol 21(5):384-390

94. Lammers M, Rose R, Scrima A, Wittinghofer A (2005) The regulation of mDial by autoinhibition and its release by Rho*GTP. EMBO J 24(23):4176-4187

95. Wallar BJ, Stropich BN, Schoenherr JA, Holman HA, Kitchen SM, Alberts AS (2006) The basic region of the diaphanousautoregulatory domain (DAD) is required for autoregulatory interactions with the diaphanous-related formin inhibitory domain. J Biol Chem 281(7):4300-4307

96. Li F, Higgs HN (2003) The mouse Formin mDial is a potent actin nucleation factor regulated by autoinhibition. Curr Biol 13(15): 1335-1340

97. Liu W, Sato A, Khadka D, Bharti R, Diaz H, Runnels LW, Habas R (2008) Mechanism of activation of the Formin protein Daam1. Proc Natl Acad Sci USA 105(1):210-215

98. Nezami AG, Poy F, Eck MJ (2006) Structure of the autoinhibitory switch in formin mDia1. Structure 14(2):257-263
99. Rose R, Weyand M, Lammers M, Ishizaki T, Ahmadian MR, Wittinghofer A (2005) Structural and mechanistic insights into the interaction between Rho and mammalian Dia. Nature 435(7041):513-518

100. Seth A, Otomo C, Rosen MK (2006) Autoinhibition regulates cellular localization and actin assembly activity of the diaphanous-related formins FRLalpha and mDia1. J Cell Biol 174(5):701-713

101. Lees JG, Bach CT, O’Neill GM (2011) Interior decoration: tropomyosin in actin dynamics and cell migration. Cell Adhes Migr 5(2):181-186

102. Vindin H, Gunning P (2013) Cytoskeletal tropomyosins: choreographers of actin filament functional diversity. J Muscle Res Cell Motil 34(3-4):261-274

103. Liu HP, Bretscher A (1989) Disruption of the single tropomyosin gene in yeast results in the disappearance of actin cables from the cytoskeleton. Cell 57(2):233-242

104. Skau CT, Neidt EM, Kovar DR (2009) Role of tropomyosin in formin-mediated contractile ring assembly in fission yeast. Mol Biol Cell 20(8):2160-2173

105. Chesarone-Cataldo M, Guerin C, Yu JH, Wedlich-Soldner R, Blanchoin L, Goode BL (2011) The myosin passenger protein Smy 1 controls actin cable structure and dynamics by acting as a formin damper. Dev Cell 21(2):217-230

106. Eskin JA, Rankova A, Johnston AB, Alioto SL, Goode BL (2016) Common formin-regulating sequences in Smy1 and Bud14 are required for the control of actin cable assembly in vivo. Mol Biol Cell 27:828-837

107. Mohapatra L, Goode BL, Kondev J (2015) Antenna mechanism of length control of actin cables. PLoS Comput Biol 11(6):e1004160

108. Chesarone M, Gould CJ, Moseley JB, Goode BL (2009) Displacement of formins from growing barbed ends by bud14 is critical for actin cable architecture and function. Dev Cell 16(2):292-302

109. Gould CJ, Chesarone-Cataldo M, Alioto SL, Salin B, Sagot I, Goode BL (2014) Saccharomyces cerevisiae Kelch proteins and Bud14 protein form a stable 520-kDa formin regulatory complex that controls actin cable assembly and cell morphogenesis. J Biol Chem 289(26):18290-18301

110. Philips J, Herskowitz I (1998) Identification of Kel1p, a kelch domain-containing protein involved in cell fusion and morphology in Saccharomyces cerevisiae. J Cell Biol 143(2):375-389

111. Oh Y, Schreiter J, Nishihama R, Wloka C, Bi E (2013) Targeting and functional mechanisms of the cytokinesis-related F-BAR protein Hofl during the cell cycle. Mol Biol Cell 24(9):1305-1320

112. Vallen EA, Caviston J, Bi E (2000) Roles of Hof1p, Bnilp, Bnrlp, and myolp in cytokinesis in Saccharomyces cerevisiae. Mol Biol Cell 11(2):593-611

113. Graziano BR, Yu HY, Alioto SL, Eskin JA, Ydenberg CA, Waterman DP, Garabedian M, Goode BL (2014) The F-BAR protein Hof1 tunes formin activity to sculpt actin cables during polarized growth. Mol Biol Cell 25(11):1730-1743

114. Buttery SM, Kono K, Stokasimov E, Pellman D (2012) Regulation of the formin Bnr1 by septins anda MARK/Par1-family septin-associated kinase. Mol Biol Cell 23(20):4041-4053

115. Wang J, Neo SP, Cai M (2009) Regulation of the yeast formin Bnilp by the actin-regulating kinase Prk1p. Traffic 10(5):528-535

116. Matheos D, Metodiev M, Muller E, Stone D, Rose MD (2004) Pheromone-induced polarization is dependent on the Fus $3 p$ MAPK acting through the formin Bnilp. J Cell Biol 165(1):99-109 
117. Bloom J, Cristea IM, Procko AL, Lubkov V, Chait BT, Snyder M, Cross FR (2011) Global analysis of Cdc14 phosphatase reveals diverse roles in mitotic processes. J Biol Chem 286(7):5434-5445

118. Orii M, Kono K, Wen HI, Nakanishi M (2016) PP1-dependent formin Bnrl dephosphorylation and delocalization from a cell division site. PLoS One 11(1):e0146941

119. Kono K, Saeki Y, Yoshida S, Tanaka K, Pellman D (2012) Proteasomal degradation resolves competition between cell polarization and cellular wound healing. Cell 150(1):151-164

120. VerPlank L, Li R (2005) Cell cycle-regulated trafficking of Chs2 controls actomyosin ring stability during cytokinesis. Mol Biol Cell 16(5):2529-2543

121. Amberg DC, Zahner JE, Mulholland JW, Pringle JR, Botstein D (1997) Aip3p/Bud6p, a yeast actin-interacting protein that is involved in morphogenesis and the selection of bipolar budding sites. Mol Biol Cell 8(4):729-753

122. Finger FP, Hughes TE, Novick P (1998) Sec3p is a spatial landmark for polarized secretion in budding yeast. Cell 92(4):559-571

123. Meitinger F, Richter H, Heisel S, Hub B, Seufert W, Pereira G (2013) A safeguard mechanism regulates Rho GTPases to coordinate cytokinesis with the establishment of cell polarity. PLoS Biol 11(2):e1001495

124. Tolliday N, VerPlank L, Li R (2002) Rho1 directs formin-mediated actin ring assembly during budding yeast cytokinesis. Curr Biol 12(21):1864-1870

125. Annan RB, Lee AY, Reid ID, Sayad A, Whiteway M, Hallett M, Thomas DY (2009) A biochemical genomics screen for substrates of Ste20p kinase enables the in silico prediction of novel substrates. PLoS One 4(12): e8279

126. Tong Z, Gao XD, Howell AS, Bose I, Lew DJ, Bi E (2007) Adjacent positioning of cellular structures enabled by a $\mathrm{Cdc} 42$ GTPase-activating protein-mediated zone of inhibition. J Cell Biol 179(7):1375-1384

127. Ziman M, Preuss D, Mulholland J, O'Brien JM, Botstein D, Johnson DI (1993) Subcellular localization of Cdc42p, a Saccharomyces cerevisiae GTP-binding protein involved in the control of cell polarity. Mol Biol Cell 4(12):1307-1316

128. Atkins BD, Yoshida S, Saito K, Wu CF, Lew DJ, Pellman D (2013) Inhibition of $\mathrm{Cdc} 42$ during mitotic exit is required for cytokinesis. J Cell Biol 202(2):231-240

129. Yoshida S, Bartolini S, Pellman D (2009) Mechanisms for concentrating Rho1 during cytokinesis. Genes Dev 23(7):810-823. doi:10.1101/gad.1785209

130. Yoshida S, Kono K, Lowery DM, Bartolini S, Yaffe MB, Ohya Y, Pellman D (2006) Polo-like kinase Cdc5 controls the local activation of Rho1 to promote cytokinesis. Science 313(5783):108-111

131. Heider MR, Gu M, Duffy CM, Mirza AM, Marcotte LL, Walls AC, Farrall N, Hakhverdyan Z, Field MC, Rout MP, Frost A, Munson M (2016) Subunit connectivity, assembly determinants and architecture of the yeast exocyst complex. Nat Struct Mol Biol 23(1):59-66

132. TerBush DR, Maurice T, Roth D, Novick P (1996) The Exocyst is a multiprotein complex required for exocytosis in Saccharomyces cerevisiae. EMBO J 15(23):6483-6494

133. TerBush DR, Novick $P$ (1995) Sec6, Sec8, and Sec15 are components of a multisubunit complex which localizes to small bud tips in Saccharomyces cerevisiae. J Cell Biol 130(2):299-312

134. Aronov S, Gerst JE (2004) Involvement of the late secretory pathway in actin regulation and mRNA transport in yeast. J Biol Chem 279(35):36962-36971
135. Mulholland J, Wesp A, Riezman H, Botstein D (1997) Yeast actin cytoskeleton mutants accumulate a new class of Golgiderived secretary vesicle. Mol Biol Cell 8(8):1481-1499

136. Jourdain I, Dooley HC, Toda T (2012) Fission yeast sec3 bridges the exocyst complex to the actin cytoskeleton. Traffic 13(11):1481-1495

137. Adamo JE, Moskow JJ, Gladfelter AS, Viterbo D, Lew DJ, Brennwald PJ (2001) Yeast Cdc42 functions at a late step in exocytosis, specifically during polarized growth of the emerging bud. J Cell Biol 155(4):581-592

138. Roumanie O, Wu H, Molk JN, Rossi G, Bloom K, Brennwald P (2005) Rho GTPase regulation of exocytosis in yeast is independent of GTP hydrolysis and polarization of the exocyst complex. J Cell Biol 170(4):583-594

139. Oh Y, Bi E (2010) Septin structure and function in yeast and beyond. Trends Cell Biol 21(3):141-148

140. Weirich CS, Erzberger JP, Barral Y (2008) The septin family of GTPases: architecture and dynamics. Nat Rev Mol Cell Biol 9(6):478-489

141. Hartwell LH (1971) Genetic control of the cell division cycle in yeast. IV. Genes controlling bud emergence and cytokinesis. Exp Cell Res 69(2):265-276

142. Berlin A, Paoletti A, Chang F (2003) Mid2p stabilizes septin rings during cytokinesis in fission yeast. $\mathrm{J}$ Cell Biol 160(7): 1083-1092

143. Tasto JJ, Morrell JL, Gould KL (2003) An anillin homologue, Mid2p, acts during fission yeast cytokinesis to organize the septin ring and promote cell separation. J Cell Biol 160(7):1093-1103

144. An H, Morrell JL, Jennings JL, Link AJ, Gould KL (2004) Requirements of fission yeast septins for complex formation, localization, and function. Mol Biol Cell 15(12):5551-5564

145. Martin-Cuadrado AB, Morrell JL, Konomi M, An H, Petit C, Osumi M, Balasubramanian M, Gould KL, Del Rey F, de Aldana CR (2005) Role of septins and the exocyst complex in the function of hydrolytic enzymes responsible for fission yeast cell separation. Mol Biol Cell 16(10):4867-4881

146. Bertin A, McMurray MA, Grob P, Park SS, Garcia G 3rd, Patanwala I, Ng HL, Alber T, Thorner J, Nogales E (2008) Saccharomyces cerevisiae septins: supramolecular organization of heterooligomers and the mechanism of filament assembly. Proc Natl Acad Sci USA 105(24):8274-8279

147. Garcia G 3rd, Bertin A, Li Z, Song Y, McMurray MA, Thorner J, Nogales E (2011) Subunit-dependent modulation of septin assembly: budding yeast septin Shs1 promotes ring and gauze formation. J Cell Biol 195(6):993-1004

148. Bridges AA, Zhang H, Mehta SB, Occhipinti P, Tani T, Gladfelter AS (2014) Septin assemblies form by diffusion-driven annealing on membranes. Proc Natl Acad Sci USA 111(6):2146-2151

149. Lee PR, Song S, Ro HS, Park CJ, Lippincott J, Li R, Pringle JR, De Virgilio C, Longtine MS, Lee KS (2002) Bni5p, a septininteracting protein, is required for normal septin function and cytokinesis in Saccharomyces cerevisiae. Mol Cell Biol 22(19):6906-6920

150. Patasi C, Godocikova J, Michlikova S, Nie Y, Kacerikova R, Kvalova K, Raunser S, Farkasovsky M (2015) The role of Bni5 in the regulation of septin higher-order structure formation. Biol Chem 396(12):1325-1337

151. Fang X, Luo J, Nishihama R, Wloka C, Dravis C, Travaglia M, Iwase M, Vallen EA, Bi E (2010) Biphasic targeting and cleavage furrow ingression directed by the tail of a myosin II. J Cell Biol 191(7):1333-1350

152. Finnigan GC, Booth EA, Duvalyan A, Liao EN, Thorner J (2015) The carboxy-terminal tails of septins Cdc11 and Shs1 
recruit myosin-II binding factor Bni5 to the bud neck in Saccharomyces cerevisiae. Genetics 200(3):843-862

153. Schneider C, Grois J, Renz C, Gronemeyer T, Johnsson N (2013) Septin rings act as a template for myosin higher-order structures and inhibit redundant polarity establishment. J Cell Sci 126(Pt 15):3390-3400

154. Bertin A, McMurray MA, Thai L, Garcia G 3rd, Votin V, Grob P, Allyn T, Thorner J, Nogales E (2010) Phosphatidylinositol4,5-bisphosphate promotes budding yeast septin filament assembly and organization. J Mol Biol 404:711-731

155. Casamayor A, Snyder M (2003) Molecular dissection of a yeast septin: distinct domains are required for septin interaction, localization, and function. Mol Cell Biol 23(8):2762-2777

156. Zhang J, Kong C, Xie H, McPherson PS, Grinstein S, Trimble WS (1999) Phosphatidylinositol polyphosphate binding to the mammalian septin H5 is modulated by GTP. Curr Biol 9(24):1458-1467

157. Garrenton LS, Stefan CJ, McMurray MA, Emr SD, Thorner J (2010) Pheromone-induced anisotropy in yeast plasma membrane phosphatidylinositol-4,5-bisphosphate distribution is required for MAPK signaling. Proc Natl Acad Sci USA 107(26):11805-11810

158. McMurray MA, Bertin A, Garcia G 3rd, Lam L, Nogales E, Thorner J (2011) Septin filament formation is essential in budding yeast. Dev Cell 20(4):540-549

159. Caviston JP, Longtine M, Pringle JR, Bi E (2003) The role of Cdc42p GTPase-activating proteins in assembly of the septin ring in yeast. Mol Biol Cell 14(10):4051-4066

160. Dobbelaere J, Gentry MS, Hallberg RL, Barral Y (2003) Phosphorylation-dependent regulation of septin dynamics during the cell cycle. Dev Cell 4(3):345-357

161. Lippincott J, Shannon KB, Shou W, Deshaies RJ, Li R (2001) The Tem1 small GTPase controls actomyosin and septin dynamics during cytokinesis. J Cell Sci 114(Pt 7):1379-1386

162. Wloka C, Nishihama R, Onishi M, Oh Y, Hanna J, Pringle JR, Krauss M, Bi E (2011) Evidence that a septin diffusion barrier is dispensable for cytokinesis in budding yeast. Biol Chem 392(8-9):813-829

163. Demay BS, Bai X, Howard L, Occhipinti P, Meseroll RA, Spiliotis ET, Oldenbourg R, Gladfelter AS (2011) Septin filaments exhibit a dynamic, paired organization that is conserved from yeast to mammals. J Cell Biol 193(6):1065-1081

164. Vrabioiu AM, Mitchison TJ (2006) Structural insights into yeast septin organization from polarized fluorescence microscopy. Nature 443(7110):466-469

165. Byers B, Goetsch L (1976) A highly ordered ring of membrane-associated filaments in budding yeast. J Cell Biol 69(3):717-721

166. Ong K, Wloka C, Okada S, Svitkina T, Bi E (2014) Architecture and dynamic remodelling of the septin cytoskeleton during the cell cycle. Nat Commun 5:5698

167. Cid VJ, Adamikova L, Sanchez M, Molina M, Nombela C (2001) Cell cycle control of septin ring dynamics in the budding yeast. Microbiology 147(Pt 6):1437-1450

168. Gladfelter AS, Bose I, Zyla TR, Bardes ES, Lew DJ (2002) Septin ring assembly involves cycles of GTP loading and hydrolysis by Cdc42p. J Cell Biol 156(2):315-326. doi:10.1083/ jcb.200109062

169. Sadian Y, Gatsogiannis C, Patasi C, Hofnagel O, Goody RS, Farkasovsky M, Raunser S (2013) The role of Cdc42 and Gic1 in the regulation of septin filament formation and dissociation. eLife 2:e01085

170. Okada S, Leda M, Hanna J, Savage NS, Bi E, Goryachev AB (2013) Daughter cell identity emerges from the interplay of cdc42, septins, and exocytosis. Dev Cell 26(2):148-161
171. McMurray MA, Thorner J (2008) Septin stability and recycling during dynamic structural transitions in cell division and development. Curr Biol 18(16):1203-1208

172. Piekny AJ, Maddox AS (2010) The myriad roles of anillin during cytokinesis. Semin Cell Dev Biol 21(9):881-891

173. Kang PJ, Angerman E, Jung CH, Park HO (2012) Bud4 mediates the cell-type-specific assembly of the axial landmark in budding yeast. J Cell Sci 125(Pt 16):3840-3849

174. Sanders SL, Herskowitz I (1996) The BUD4 protein of yeast, required for axial budding, is localized to the mother/BUD neck in a cell cycle-dependent manner. J Cell Biol 134(2):413-427

175. Wu H, Guo J, Zhou YT, Gao XD (2015) The anillin-related region of Bud4 is the major functional determinant for Bud4's function in septin organization during bud growth and axial bud site selection in budding yeast. Eukaryot Cell 14(3):241-251

176. Eluere R, Varlet I, Bernadac A, Simon MN (2012) Cdk and the anillin homolog Bud4 define a new pathway regulating septin organization in yeast. Cell Cycle 11(1):151-158

177. Merlini L, Bolognesi A, Juanes MA, Vandermoere F, Courtellemont T, Pascolutti R, Seveno M, Barral Y, Piatti S (2015) Rho1- and Pkc1-dependent phosphorylation of the F-BAR protein Syp1 contributes to septin ring assembly. Mol Biol Cell 26(18):3245-3262

178. Qiu W, Neo SP, Yu X, Cai M (2008) A novel septin-associated protein, Syp1p, is required for normal cell cycle-dependent septin cytoskeleton dynamics in yeast. Genetics 180(3):1445-1457

179. Reider A, Barker SL, Mishra SK, Im YJ, Maldonado-Baez L, Hurley JH, Traub LM, Wendland B (2009) Syp1 is a conserved endocytic adaptor that contains domains involved in cargo selection and membrane tubulation. EMBO J 28(20):3103-3116

180. Stimpson HE, Toret CP, Cheng AT, Pauly BS, Drubin DG (2009) Early-arriving Syp1p and Ede1p function in endocytic site placement and formation in budding yeast. Mol Biol Cell 20(22):4640-4651

181. Kuilman T, Maiolica A, Godfrey M, Scheidel N, Aebersold R, Uhlmann F (2014) Identification of Cdk targets that control cytokinesis. EMBO J 34(1):81-96

182. Caudron F, Barral Y (2009) Septins and the lateral compartmentalization of eukaryotic membranes. Dev Cell 16(4):493-506

183. Saarikangas J, Barral Y (2011) The emerging functions of septins in metazoans. EMBO Rep 12(11):1118-1126

184. Castillon GA, Adames NR, Rosello CH, Seidel HS, Longtine MS, Cooper JA, Heil-Chapdelaine RA (2003) Septins have a dual role in controlling mitotic exit in budding yeast. Curr Biol 13(8):654-658

185. Shepard KA, Gerber AP, Jambhekar A, Takizawa PA, Brown PO, Herschlag D, DeRisi JL, Vale RD (2003) Widespread cytoplasmic mRNA transport in yeast: identification of 22 budlocalized transcripts using DNA microarray analysis. Proc Natl Acad Sci USA 100(20):11429-11434

186. Takizawa PA, DeRisi JL, Wilhelm JE, Vale RD (2000) Plasma membrane compartmentalization in yeast by messenger RNA transport and a septin diffusion barrier. Science 290(5490):341-344

187. Luedeke C, Frei SB, Sbalzarini I, Schwarz H, Spang A, Barral Y (2005) Septin-dependent compartmentalization of the endoplasmic reticulum during yeast polarized growth. J Cell Biol 169(6):897-908

188. Kusch J, Meyer A, Snyder MP, Barral Y (2002) Microtubule capture by the cleavage apparatus is required for proper spindle positioning in yeast. Genes Dev 16(13):1627-1639

189. King K, Jin M, Lew D (2012) Roles of Hsl1p and Hsl7p in Swe1p degradation: beyond septin tethering. Eukaryot Cell 11(12):1496-1502 
190. Longtine MS, Theesfeld CL, McMillan JN, Weaver E, Pringle JR, Lew DJ (2000) Septin-dependent assembly of a cell cycleregulatory module in Saccharomyces cerevisiae. Mol Cell Biol 20(11):4049-4061

191. McMillan JN, Longtine MS, Sia RA, Theesfeld CL, Bardes ES, Pringle JR, Lew DJ (1999) The morphogenesis checkpoint in Saccharomyces cerevisiae: cell cycle control of Swe1p degradation by Hsl1p and Hsl7p. Mol Cell Biol 19(10):6929-6939

192. Shulewitz MJ, Inouye CJ, Thorner J (1999) Hsl7 localizes to a septin ring and serves as an adapter in a regulatory pathway that relieves tyrosine phosphorylation of $\mathrm{Cdc} 28$ protein kinase in Saccharomyces cerevisiae. Mol Cell Biol 19(10):7123-7137

193. Versele M, Thorner J (2005) Some assembly required: yeast septins provide the instruction manual. Trends Cell Biol 15(8):414-424

194. Sreenivasan A, Kellogg D (1999) The elm1 kinase functions in a mitotic signaling network in budding yeast. Mol Cell Biol 19(12):7983-7994

195. Asano S, Park JE, Yu LR, Zhou M, Sakchaisri K, Park CJ, Kang YH, Thorner J, Veenstra TD, Lee KS (2006) Direct phosphorylation and activation of a Nim1-related kinase Gin4 by Elm1 in budding yeast. J Biol Chem 281(37):27090-27098

196. Mortensen EM, McDonald H, Yates J 3rd, Kellogg DR (2002) Cell cycle-dependent assembly of a Gin4-septin complex. Mol Biol Cell 13(6):2091-2105

197. Egelhofer TA, Villen J, McCusker D, Gygi SP, Kellogg DR (2008) The septins function in G1 pathways that influence the pattern of cell growth in budding yeast. PLoS One 3(4):e2022

198. Tang CS, Reed SI (2002) Phosphorylation of the septin cdc3 in g1 by the cdc28 kinase is essential for efficient septin ring disassembly. Cell Cycle 1(1):42-49

199. Dobbelaere J, Barral Y (2004) Spatial coordination of cytokinetic events by compartmentalization of the cell cortex. Science 305(5682):393-396

200. Johnson ES, Blobel G (1999) Cell cycle-regulated attachment of the ubiquitin-related protein SUMO to the yeast septins. J Cell Biol 147(5):981-994

201. Johnson ES, Gupta AA (2001) An E3-like factor that promotes SUMO conjugation to the yeast septins. Cell 106(6):735-744

202. Chahwan R, Gravel S, Matsusaka T, Jackson SP (2013) Dma/ RNF8 proteins are evolutionarily conserved E3 ubiquitin ligases that target septins. Cell Cycle 12(6):1000-1008

203. Fraschini R, Bilotta D, Lucchini G, Piatti S (2004) Functional characterization of Dma1 and Dma2, the budding yeast homologues of Schizosaccharomyces pombe Dma1 and human Chfr. Mol Biol Cell 15(8):3796-3810

204. Merlini L, Fraschini R, Boettcher B, Barral Y, Lucchini G, Piatti S (2012) Budding yeast dma proteins control septin dynamics and the spindle position checkpoint by promoting the recruitment of the Elm1 kinase to the bud neck. PLoS Genet $8(4): \mathrm{e} 1002670$

205. Mitchell L, Lau A, Lambert JP, Zhou H, Fong Y, Couture JF, Figeys D, Baetz K (2011) Regulation of septin dynamics by the Saccharomyces cerevisiae lysine acetyltransferase NuA4. PLoS One 6(10):e25336

206. Kinoshita M, Field CM, Coughlin ML, Straight AF, Mitchison TJ (2002) Self- and actin-templated assembly of mammalian septins. Dev Cell 3(6):791-802

207. Vrabioiu AM, Mitchison TJ (2007) Symmetry of septin hourglass and ring structures. J Mol Biol 372(1):37-49

208. Kozubowski L, Larson JR, Tatchell K (2005) Role of the septin ring in the asymmetric localization of proteins at the mother-bud neck in Saccharomyces cerevisiae. Mol Biol Cell 16(8):3455-3466

209. Longtine MS, Fares H, Pringle JR (1998) Role of the yeast Gin $4 p$ protein kinase in septin assembly and the relationship between septin assembly and septin function. J Cell Biol 143(3):719-736

210. Glotzer M (2005) The molecular requirements for cytokinesis. Science 307(5716):1735-1739

211. Rancati G, Pavelka N, Fleharty B, Noll A, Trimble R, Walton K, Perera A, Staehling-Hampton K, Seidel CW, Li R (2008) Aneuploidy underlies rapid adaptive evolution of yeast cells deprived of a conserved cytokinesis motor. Cell 135(5):879-893

212. Schmidt M, Bowers B, Varma A, Roh DH, Cabib E (2002) In budding yeast, contraction of the actomyosin ring and formation of the primary septum at cytokinesis depend on each other. J Cell Sci 115(Pt 2):293-302

213. Tolliday N, Pitcher M, Li R (2003) Direct evidence for a critical role of myosin II in budding yeast cytokinesis and the evolvability of new cytokinetic mechanisms in the absence of myosin II. Mol Biol Cell 14(2):798-809

214. Luo J, Vallen EA, Dravis C, Tcheperegine SE, Drees B, Bi E (2004) Identification and functional analysis of the essential and regulatory light chains of the only type II myosin Myolp in Saccharomyces cerevisiae. J Cell Biol 165(6):843-855

215. Watts FZ, Shiels G, Orr E (1987) The yeast MYO1 gene encoding a myosin-like protein required for cell division. EMBO J 6(11):3499-3505

216. Boyne JR, Yosuf HM, Bieganowski P, Brenner C, Price C (2000) Yeast myosin light chain, Mlc1p, interacts with both IQGAP and class II myosin to effect cytokinesis. J Cell Sci 113(Pt 24):4533-4543

217. Epp JA, Chant J (1997) An IQGAP-related protein controls actin-ring formation and cytokinesis in yeast. Curr Biol 7(12):921-929

218. Shannon KB, Li R (1999) The multiple roles of Cyk1p in the assembly and function of the actomyosin ring in budding yeast. Mol Biol Cell 10(2):283-296

219. Shannon KB, Li R (2000) A myosin light chain mediates the localization of the budding yeast IQGAP-like protein during contractile ring formation. Curr Biol 10(12):727-730

220. Tian C, Wu Y, Johnsson N (2014) Stepwise and cooperative assembly of a cytokinetic core complex in Saccharomyces cerevisiae. J Cell Sci 127(Pt 16):3614-3624

221. Feng Z, Okada S, Cai G, Zhou B, Bi E (2015) MyosinII heavy chain and formin mediate the targeting of myosin essential light chain to the division site before and during cytokinesis. Mol Biol Cell 26(7):1211-1224. doi:10.1091/mbc.E14-09-1363

222. Carnahan RH, Gould KL (2003) The PCH family protein, $\mathrm{Cdc} 15 \mathrm{p}$, recruits two $\mathrm{F}$-actin nucleation pathways to coordinate cytokinetic actin ring formation in Schizosaccharomyces pombe. J Cell Biol 162(5):851-862. doi:10.1083/jcb.200305012

223. Fankhauser C, Reymond A, Cerutti L, Utzig S, Hofmann K, Simanis V (1995) The $S$. pombe cdc15 gene is a key element in the reorganization of F-actin at mitosis. Cell 82(3):435-444

224. Laporte D, Coffman VC, Lee IJ, Wu JQ (2011) Assembly and architecture of precursor nodes during fission yeast cytokinesis. J Cell Biol 192(6):1005-1021

225. Wachtler V, Huang Y, Karagiannis J, Balasubramanian MK (2006) Cell cycle-dependent roles for the FCH-domain protein $\mathrm{Cdc} 15 \mathrm{p}$ in formation of the actomyosin ring in Schizosaccharomyces pombe. Mol Biol Cell 17(7):3254-3266

226. Willet AH, McDonald NA, Bohnert KA, Baird MA, Allen JR, Davidson MW, Gould KL (2015) The F-BAR Cdc15 promotes contractile ring formation through the direct recruitment of the formin Cdc12. J Cell Biol 208(4):391-399

227. Lippincott J, Li R (1998) Dual function of Cyk2, a cdc15/ PSTPIP family protein, in regulating actomyosin ring dynamics and septin distribution. J Cell Biol 143(7):1947-1960

228. Meitinger F, Boehm ME, Hofmann A, Hub B, Zentgraf H, Lehmann WD, Pereira G (2011) Phosphorylation-dependent 
regulation of the F-BAR protein Hof1 during cytokinesis. Genes Dev 25(8):875-888

229. Nkosi PJ, Targosz BS, Labib K, Sanchez-Diaz A (2013) Hof1 and Rvs 167 have redundant roles in actomyosin ring function during cytokinesis in budding yeast. PLoS One 8(2):e57846

230. Huckaba TM, Lipkin T, Pon LA (2006) Roles of type II myosin and a tropomyosin isoform in retrograde actin flow in budding yeast. J Cell Biol 175(6):957-969

231. Wloka C, Vallen EA, The L, Fang X, Oh Y, Bi E (2013) Immobile myosin-II plays a scaffolding role during cytokinesis in budding yeast. J Cell Biol 200(3):271-286

232. Piekny A, Werner M, Glotzer M (2005) Cytokinesis: welcome to the Rho zone. Trends Cell Biol 15(12):651-658

233. Pelham RJ, Chang F (2002) Actin dynamics in the contractile ring during cytokinesis in fission yeast. Nature 419(6902):82-86

234. Fukata M, Kuroda S, Fujii K, Nakamura T, Shoji I, Matsuura Y, Okawa K, Iwamatsu A, Kikuchi A, Kaibuchi K (1997) Regulation of cross-linking of actin filament by IQGAP1, a target for Cdc42. J Biol Chem 272(47):29579-29583

235. Hart MJ, Callow MG, Souza B, Polakis P (1996) IQGAP1, a calmodulin-binding protein with a rasGAP-related domain, is a potential effector for cdc42Hs. EMBO J 15(12):2997-3005

236. Le Clainche C, Schlaepfer D, Ferrari A, Klingauf M, Grohmanova K, Veligodskiy A, Didry D, Le D, Egile C, Carlier MF, Kroschewski R (2007) IQGAP1 stimulates actin assembly through the N-WASP-Arp2/3 pathway. J Biol Chem 282(1):426-435

237. Brandt DT, Marion S, Griffiths G, Watanabe T, Kaibuchi K, Grosse R (2007) Dia1 and IQGAP1 interact in cell migration and phagocytic cup formation. J Cell Biol 178(2):193-200

238. Li CR, Wang YM, Wang Y (2008) The IQGAP Iqg1 is a regulatory target of CDK for cytokinesis in Candida albicans. EMBO J 27(22):2998-3010

239. Huxley H, Hanson J (1954) Changes in the cross-striations of muscle during contraction and stretch and their structural interpretation. Nature 173(4412):973-976

240. Huxley HE (1969) The mechanism of muscular contraction. Science 164(3886):1356-1365

241. Tully GH, Nishihama R, Pringle JR, Morgan DO (2009) The anaphase-promoting complex promotes actomyosin-ring disassembly during cytokinesis in yeast. Mol Biol Cell 20(4):1201-1212

242. Lord M, Laves E, Pollard TD (2005) Cytokinesis depends on the motor domains of myosin-II in fission yeast but not in budding yeast. Mol Biol Cell 16(11):5346-5355

243. Mendes Pinto I, Rubinstein B, Kucharavy A, Unruh JR, Li R (2012) Actin depolymerization drives actomyosin ring contraction during budding yeast cytokinesis. Dev Cell 22(6): 1247-1260

244. Rahal R, Amon A (2008) The Polo-like kinase Cdc5 interacts with FEAR network components and Cdc14. Cell Cycle 7(20):3262-3272

245. Zumdieck A, Kruse K, Bringmann H, Hyman AA, Julicher F (2007) Stress generation and filament turnover during actin ring constriction. PLoS One 2(8):e696

246. Miller DP, Hall H, Chaparian R, Mara M, Mueller A, Hall MC, Shannon KB (2015) Dephosphorylation of Iqg1 by Cdc14 regulates cytokinesis in budding yeast. Mol Biol Cell 26(16):2913-2926

247. Wagner W, Bielli P, Wacha S, Ragnini-Wilson A (2002) Mlc1p promotes septum closure during cytokinesis via the IQ motifs of the vesicle motor Myo2p. EMBO J 21(23):6397-6408

248. Zhang G, Kashimshetty R, Ng KE, Tan HB, Yeong FM (2006) Exit from mitosis triggers Chs $2 p$ transport from the endoplasmic reticulum to mother-daughter neck via the secretory pathway in budding yeast. J Cell Biol 174(2):207-220

249. Chin CF, Bennett AM, Ma WK, Hall MC, Yeong FM (2012) Dependence of Chs2 ER export on dephosphorylation by cytoplasmic Cdc14 ensures that septum formation follows mitosis. Mol Biol Cell 23(1):45-58

250. Meitinger F, Petrova B, Lombardi IM, Bertazzi DT, Hub B, Zentgraf H, Pereira G (2010) Targeted localization of Inn1, Cyk 3 and Chs 2 by the mitotic-exit network regulates cytokinesis in budding yeast. J Cell Sci 123(Pt 11):1851-1861

251. Oh Y, Chang KJ, Orlean P, Wloka C, Deshaies R, Bi E (2012) Mitotic exit kinase Dbf2 directly phosphorylates chitin synthase Chs 2 to regulate cytokinesis in budding yeast. Mol Biol Cell 23(13):2445-2456

252. Chuang JS, Schekman RW (1996) Differential trafficking and timed localization of two chitin synthase proteins, Chs $2 p$ and Chs3p. J Cell Biol 135(3):597-610

253. Jendretzki A, Ciklic I, Rodicio R, Schmitz HP, Heinisch JJ (2009) Cyk3 acts in actomyosin ring independent cytokinesis by recruiting Inn1 to the yeast bud neck. Mol Genet Genomics 282(4):437-451

254. Korinek WS, Bi E, Epp JA, Wang L, Ho J, Chant J (2000) Cyk3, a novel SH3-domain protein, affects cytokinesis in yeast. Curr Biol 10(15):947-950

255. Nishihama R, Schreiter JH, Onishi M, Vallen EA, Hanna J, Moravcevic K, Lippincott MF, Han H, Lemmon MA, Pringle JR, Bi E (2009) Role of Inn1 and its interactions with Hof1 and Cyk3 in promoting cleavage furrow and septum formation in $S$. cerevisiae. J Cell Biol 185(6):995-1012

256. Onishi M, Ko N, Nishihama R, Pringle JR (2013) Distinct roles of Rho1, Cdc42, and Cyk3 in septum formation and abscission during yeast cytokinesis. J Cell Biol 202(2):311-329

257. Sanchez-Diaz A, Marchesi V, Murray S, Jones R, Pereira G, Edmondson R, Allen T, Labib K (2008) Inn1 couples contraction of the actomyosin ring to membrane ingression during cytokinesis in budding yeast. Nat Cell Biol 10(4):395-406

258. Devrekanli A, Foltman M, Roncero C, Sanchez-Diaz A, Labib K (2012) Inn1 and Cyk3 regulate chitin synthase during cytokinesis in budding yeasts. J Cell Sci 125(Pt 22):5453-5466

259. Levin DE (2011) Regulation of cell wall biogenesis in Saccharomyces cerevisiae: the cell wall integrity signaling pathway. Genetics 189(4):1145-1175

260. Lesage G, Bussey H (2006) Cell wall assembly in Saccharomyces cerevisiae. Microbiol Mol Biol Rev 70(2):317-343

261. Shaw JA, Mol PC, Bowers B, Silverman SJ, Valdivieso MH, Duran A, Cabib E (1991) The function of chitin synthases 2 and 3 in the Saccharomyces cerevisiae cell cycle. J Cell Biol 114(1):111-123

262. Sburlati A, Cabib E (1986) Chitin synthetase 2, a presumptive participant in septum formation in Saccharomyces cerevisiae. J Biol Chem 261(32):15147-15152

263. Cabib E, Schmidt M (2003) Chitin synthase III activity, but not the chitin ring, is required for remedial septa formation in budding yeast. FEMS Microbiol Lett 224(2):299-305

264. Kuranda MJ, Robbins PW (1991) Chitinase is required for cell separation during growth of Saccharomyces cerevisiae. J Biol Chem 266(29):19758-19767

265. Baladron V, Ufano S, Duenas E, Martin-Cuadrado AB, del Rey F, Vazquez de Aldana CR (2002) Eng1p, an endo-1,3-betaglucanase localized at the daughter side of the septum, is involved in cell separation in Saccharomyces cerevisiae. Eukaryot Cell 1(5):774-786

266. Kovacech B, Nasmyth K, Schuster T (1996) EGT2 gene transcription is induced predominantly by Swi5 in early G1. Mol Cell Biol 16(7):3264-3274

267. Mazanka E, Weiss EL (2010) Sequential counteracting kinases restrict an asymmetric gene expression program to early G1. Mol Biol Cell 21(16):2809-2820

268. Bardin AJ, Amon A (2001) Men and sin: what's the difference? Nat Rev Mol Cell Biol 2(11):815-826 
269. Hergovich A, Hemmings BA (2012) Hippo signalling in the G2/ $M$ cell cycle phase: lessons learned from the yeast MEN and SIN pathways. Semin Cell Dev Biol 23(7):794-802

270. Krapp A, Gulli MP, Simanis V (2004) SIN and the art of splitting the fission yeast cell. Curr Biol 14(17):R722-R730

271. Scarfone I, Piatti S (2015) Coupling spindle position with mitotic exit in budding yeast: the multifaceted role of the small GTPase Tem1. Small GTPases 6(4):1-6

272. Garcia-Rodriguez LJ, Crider DG, Gay AC, Salanueva IJ, Boldogh IR, Pon LA (2009) Mitochondrial inheritance is required for MEN-regulated cytokinesis in budding yeast. Curr Biol 19(20):1730-1735

273. Jaspersen SL, Morgan DO (2000) Cdc14 activates cdc15 to promote mitotic exit in budding yeast. Curr Biol 10(10):615-618

274. Konig C, Maekawa H, Schiebel E (2010) Mutual regulation of cyclin-dependent kinase and the mitotic exit network. J Cell Biol 188(3):351-368

275. Pereira G, Manson C, Grindlay J, Schiebel E (2002) Regulation of the Bfa1p-Bub2p complex at spindle pole bodies by the cell cycle phosphatase Cdc14p. J Cell Biol 157(3):367-379

276. Pereira G, Schiebel E (2001) The role of the yeast spindle pole body and the mammalian centrosome in regulating late mitotic events. Curr Opin Cell Biol 13(6):762-769

277. Visintin R, Craig K, Hwang ES, Prinz S, Tyers M, Amon A (1998) The phosphatase Cdc14 triggers mitotic exit by reversal of Cdk- dependent phosphorylation. Mol Cell 2(6):709-718

278. Stegmeier F, Amon A (2004) Closing mitosis: the functions of the Cdc14 phosphatase and its regulation. Annu Rev Genet 38:203-232

279. Bembenek J, Kang J, Kurischko C, Li B, Raab JR, Belanger KD, Luca FC, Yu H (2005) Crm1-mediated nuclear export of Cdc14 is required for the completion of cytokinesis in budding yeast. Cell Cycle 4(7):961-971

280. Frenz LM, Lee SE, Fesquet D, Johnston LH (2000) The budding yeast Dbf2 protein kinase localises to the centrosome and moves to the bud neck in late mitosis. J Cell Sci 113(Pt 19):3399-3408

281. Hwa Lim H, Yeong FM, Surana U (2003) Inactivation of mitotic kinase triggers translocation of MEN components to motherdaughter neck in yeast. Mol Biol Cell 14(11):4734-4743

282. Luca FC, Mody M, Kurischko C, Roof DM, Giddings TH, Winey M (2001) Saccharomyces cerevisiae Mob1p is required for cytokinesis and mitotic exit. Mol Cell Biol 21(20):6972-6983

283. Song S, Grenfell TZ, Garfield S, Erikson RL, Lee KS (2000) Essential function of the polo box of Cdc5 in subcellular localization and induction of cytokinetic structures. Mol Cell Biol 20(1):286-298

284. Xu S, Huang HK, Kaiser P, Latterich M, Hunter T (2000) Phosphorylation and spindle pole body localization of the Cdc15p mitotic regulatory protein kinase in budding yeast. Curr Biol 10(6):329-332

285. Yoshida S, Toh-e A (2001) Regulation of the localization of Dbf2 and mob1 during cell division of Saccharomyces cerevisiae. Genes Genet Syst 76(2):141-147

286. Simanis V (2003) The mitotic exit and septation initiation networks. J Cell Sci 116(Pt 21):4261-4262

287. Corbett M, Xiong Y, Boyne JR, Wright DJ, Munro E, Price C (2006) IQGAP and mitotic exit network (MEN) proteins are required for cytokinesis and re-polarization of the actin cytoskeleton in the budding yeast, Saccharomyces cerevisiae. Eur J Cell Biol 85(11):1201-1215

288. Holt LJ, Tuch BB, Villen J, Johnson AD, Gygi SP, Morgan DO (2009) Global analysis of Cdk1 substrate phosphorylation sites provides insights into evolution. Science 325(5948):1682-1686

289. Swaney DL, Beltrao P, Starita L, Guo A, Rush J, Fields S, Krogan NJ, Villen J (2013) Global analysis of phosphorylation and ubiquitylation cross-talk in protein degradation. Nat Methods 10(7):676-682

290. Naylor SG, Morgan DO (2014) Cdk1-dependent phosphorylation of Iqg1 governs actomyosin ring assembly prior to cytokinesis. J Cell Sci 127(Pt 5):1128-1137

291. Sanchez-Diaz A, Nkosi PJ, Murray S, Labib K (2012) The mitotic exit network and $\mathrm{Cdc} 14$ phosphatase initiate cytokinesis by counteracting CDK phosphorylations and blocking polarised growth. EMBO J 31(17):3620-3634

292. Bidlingmaier S, Weiss EL, Seidel C, Drubin DG, Snyder M (2001) The Cbk1p pathway is important for polarized cell growth and cell separation in Saccharomyces cerevisiae. Mol Cell Biol 21(7):2449-2462

293. Brace J, Hsu J, Weiss EL (2011) Mitotic exit control of the Saccharomyces cerevisiae Ndr/LATS kinase Cbk1 regulates daughter cell separation after cytokinesis. Mol Cell Biol 31(4):721-735 